University of South Florida

DIGITAL COMMONS

@ UNIVERSITY OF SOUTH FLORIDA
Digital Commons @ University of

South Florida

8-1-2002

\title{
Volusia County Transit Development Plan 2003-2007
}

CUTR

Follow this and additional works at: https://digitalcommons.usf.edu/cutr_nctr

\section{Scholar Commons Citation}

CUTR, "Volusia County Transit Development Plan 2003-2007" (2002). Research Reports. 223.

https://digitalcommons.usf.edu/cutr_nctr/223

This Technical Report is brought to you for free and open access by the National Center for Transit Research (NCTR) Archive (2000-2020) at Digital Commons @ University of South Florida. It has been accepted for inclusion in Research Reports by an authorized administrator of Digital Commons @ University of South Florida. For more information, please contact digitalcommons@usf.edu. 


\section{VOLUSIA COUNTY TRANSIT DEVELOPMENT PLAN 2003-2007}

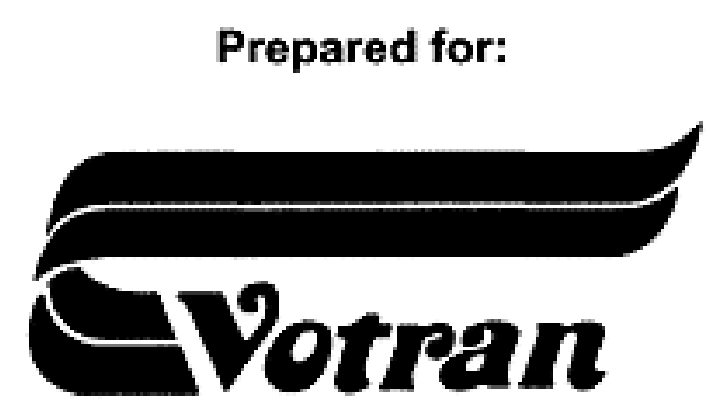

Volusia County dba VOTRAN

By:

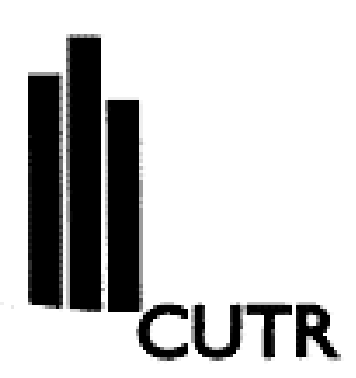

Center for Urban Transportation Research

College of Engineering

University of South Florida

August 2002 


\section{Volusia County dba VOTRAN 950 Big Tree Road \\ South Daytona, Florida 32119 \\ (386) $756-7496$ \\ Fax (386) 756-7487}

General Manager: Ken Fischer

Center for Urban Transportation Research

University of South Florida

4202 E. Fowler Avenue, CUT 100

Tampa, Florida 33620-5375

(813) 974-3120

Suncom 574-3120

Fax (813) 974-5168

Project Director: Joel R. Rey

Project Managers: Victoria A. Perk

Project Staff: $\quad$ Chandra Forem

Laurel Land

Jason Alber 


\section{TABLE OF CONTENTS}

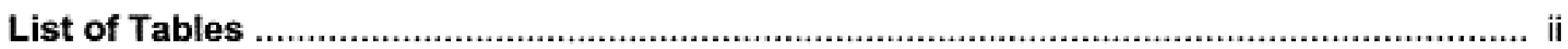

Introduction

Chapter One: An Overview and Demographic Analysis of Volusia County ......................... 2

Summary of Demographic Analysis................................................................... 3

Summary of VOTRAN On-Board Survey Results ........................................................... 3

Customer Demographics ............................................................................. 3

VOTRAN Customer Travel Behavior, Fare Usage, and Special Areas

of Concern ...................................................................................... 4

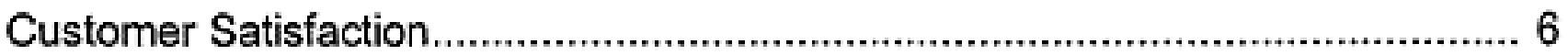

Summary of VOTRAN Operator Survey ........................................................... 7

Summary of Interviews with Key Local Officials......................................................... 7

Summary of Workshops ......................................................................................... 8

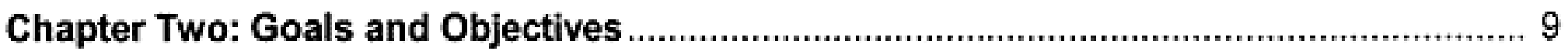

Chapter Three: Performance Evaluation of Fixed-Route Transit Service .......................... 11

Chapter Four: Performance Evaluation of Paratransit Service ..................................... 13

Chapter Five: Demand Estimation and Needs Assessment ............................................. 14

Demand Estimates.......................................................................................... 14

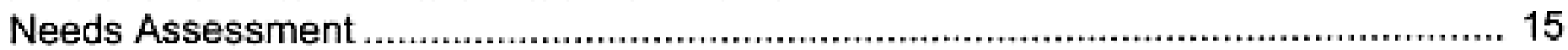

Fixed-Route Service ................................................................................ 15

Paratransit Service ................................................................................. 16

Chapter Six: Transit Alternatives and Recommendations............................................. 16

Future Direction for VOTRAN .......................................................................... 17

Five-Year Transit Development Plan: Findings and Recommendations ..................... 18

Actions to be Initiated Within the Next Year .................................................. 18

Fixed-Route Service ...................................................................... 18

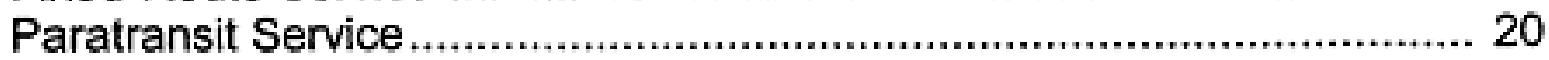

Actions to be Initiated over the Next Two-to-Three Years ................................. 20

Fixed-Route Service........................................................................ 20

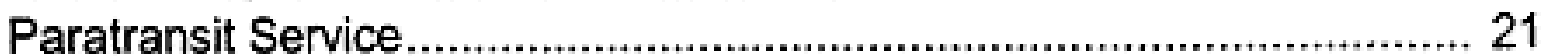

Actions to be Initiated over the Next Four-to-Five Years ................................... 21

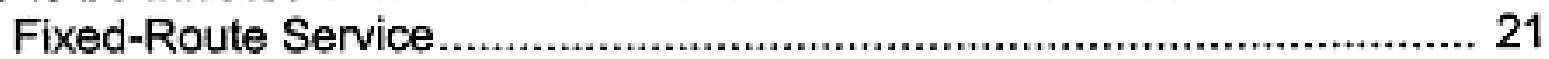

Five-Year Transit Development Plan: Financial Plan................................................... 21 


\section{List of Tables}

Table ES-1 VOTRAN Goals ..................................................................................... 10

Table ES-2 VOTRAN Performance Strengths and Weaknesses, Trend Analysis...................12

Table ES-3 VOTRAN Performance Strengths and Weaknesses, Peer Review Analysis ...... 12

Table ES-4 Fixed-Route Ridership Projections for VOTRAN (based on regression

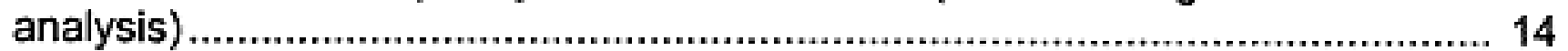

Table ES-5 ADA Demand Estimates ...................................................................... 15

Table ES-6 VOTRAN Five-Year Plan, 2003-2007, No Extra Service Over Present.............. 23

Table ES-7 VOTRAN Transit Development Plan, Estimated Costs of Funded Recommendations ................................................................................... 24

Table ES-8 VOTRAN Transit Development Plan, Estimated Costs of Unfunded Recommendations .............................................................................. 25

Table ES-9 VOTRAN Transit Development Plan, Estimated Operating and Capital Costs of Funded Recommendations by Fiscal Year ............................................... 26

Table ES-10 VOTRAN Transit Development Plan, Estimated Operating and Capital Costs of Unfunded Recommendations by Fiscal Year .......................................... 27

Table ES-11 VOTRAN Transit Development Plan, Distribution of Estimated Operating Costs of Recommendations Among Potential Funding Sources by Fiscal Year.......... 28

Table ES-12 VOTRAN Transit Development Plan, Distribution of Estimated Capital Costs of Recommendations Among Potential Funding Sources by Fiscal Year.......... 29

Table ES-13 VOTRAN Transit Development Plan, Operating and Capital Budget Summary, Projected Expenses, Revenues, and Unfunded Needs 30 


\section{VOLUSIA COUNTY TRANSIT DEVELOPMENT PLAN: 2003 - 2007 Executive Summary}

\section{INTRODUCTION}

VOTRAN, Volusia County's transit system, contracted with the Center for Urban Transportation Research (CUTR) to prepare the major five-year Transit Development Plan (TDP) update for the County. Each public transportation agency in the State of Florida that receives State Block Grant funding is required by the Florida Department of Transportation (FDOT) to generate a TDP. The intent of this requirement is to ensure that the provision of public transportation service is consistent with the travel needs and mobility goals of the community. By establishing a strategic context for transit planning, the TDP can serve as guide in the future development of the transit system.

FDOT's intention in requiring TDPS is to encourage the consideration of strategic issues, mobility needs within the context of overall planning and development efforts, and prioritization of needs in the form of a staged implementation plan. Relevant features include an extensive focus on transit, an emphasis on transit's role at the community level, and explicit consideration of external factors affecting the viability of the transit system. Several concepts of strategic planning (vision, external orientation, and future focus) are applicable in the preparation of a TDP.

Volusia County's transit system was originally established by county ordinance as the East Volusia Transit Authority and was, initially, a division of the County. As of October 1, 1993, however, the East Volusia Transit Authority ceased to exist when Volusia County dba VOTRAN became part of the County's General Fund and had its service area expanded countywide. The system is governed by the Volusia County Council, who all serve as members of the sevenmember Board of Directors. The Council includes five district members and two at-large members. VOTRAN provides public transportation services by directly operating fixed-route motorbus, vanpool, and paratransit services to the community. The system also contracts for one of its fixed routes (i.e., the 1-4 Link express commuter bus service VOTRAN operates with LYNX Transit) and some of the demand-response services that it provides.

On November 1, 1993, VOTRAN was named the Community Transportation Coordinator (CTC) of Volusia County. In addition, VOTRAN took over the Council on Aging Transportation Services (COATS) on July 3,1994, and implemented Sunday service on June 12, 1994. At the start of the 1995 fiscal year, VOTRAN took over operation of the fixed-route motorbus service in New Smyrna Beach that previously had been operated by Smyrna Transit System. It was during this same time (October 1994) that VOTRAN also began operating three fixed routes in the western portion of Volusia County. Then, in June 1995, VOTRAN implemented EastWest connector service. VOTRAN's most recent route addition, the Route 24 from Brandywine 
Village Shopping Center to Pierson in Northwest Volusia, resulted from the system's 1999 Comprehensive Operations Analysis, which also led to other various route structure modifications that were ultimately implemented in September 2000 .

In its current configuration, the system serves Daytona Beach, Holly Hill, Ormond Beach, Ormond-by-the-Sea, South Daytona, Daytona Beach Shores, Port Orange, Ponce Inlet, New Smyrna Beach, Oak Hill, and Edgewater along the County's east coast, and Pierson, Barberville, DeLeon Springs, DeLand, Orange City, DeBary, and Deltona on the County's west side. The frequency of most routes is one hour, with a few operating half-hour headways. Service is provided seven days per week, with the exception of Thanksgiving Day, Christmas Day, and New Year's Day. Weekday and Saturday service operates primarily between 6:00 a.m. and 7:00 p.m. Sunday service is limited geographically to the core area of the Eastside, and operates mainly between 7:00 a.m. and 6:30 p.m.

Six chapters were developed for this TDP. Chapter One examines the demographic and economic conditions within Volusia County and also includes information gathered from an onboard ridership survey, a bus operator survey, interviews with several key local officials, and workshops conducted with transit users and non-users. Chapter Two outlines goals and objectives for VOTRAN and demonstrates their connection with goals specified in other planning documents. Chapter Three presents a performance review of VOTRAN's fixed-route service, including a trend analysis, a peer comparison, and an individual route evaluation. Similarly, Chapter Four contains a performance review of VOTRAN's paratransit services. Chapter Five provides ridership and demand estimates for VOTRAN service for the five-year planning period, as well as a needs assessment for the system. Finally, Chapter Six evaluates alternatives and proposes recommendations for public transportation services in Volusia County. The following sections summarize the findings from each of these chapters in the TDP.

\section{CHAPTER ONE: AN OVERVIEW AND DEMOGRAPHIC ANALYSIS OF VOLUSIA COUNTY}

The majority of this chapter is devoted to a close examination of person- and household-level demographic and economic data for Volusia County using data from the U.S. Bureau of the Census. To the extent possible, the most up-to-date information was utilized for each of the demographic characteristics presented herein. In most cases, data obtained through the 2000 Census were utilized; otherwise, data from the 1990 Census were used. When necessary, Caliper Corporation's 2002 Demographic Estimate \& Projection, a commercial database based on Census data and other government information sources was referenced. A further data source used during this report was the 2001 Florida Statistical Abstract. Specific demographic characteristics related to transit use are also analyzed, as well as information from surveys of passengers and bus operators, workshops with local advisory groups, and interviews with key local officials. 


\section{Summary of Demographic Analysis}

The population growth in Volusia County between 1990 and 2000 (19.6 percent) was not as fast as that of the State as a whole (23.5 percent during this same period). However, the county continues to be more dense (402 persons per square mile) than the overall average density for Florida (296 persons per square mile). Based on population distributions, Volusia residents are more likely to be elderly than Florida residents $(22.1$ percent versus 17.6 percent persons 65 years and older, respectively). Household income and vehicle availability data suggest that the population is largely middle class: 32.7 percent of the households in Volusia have annual incomes between $\$ 15,000$ and $\$ 34,999$ and 42.4 percent of the households have one vehicle available for use.

As for employment, the labor force participation rate for Volusia County ( 77.5 percent) is slightly higher than that for Florida (77.0 percent), and Volusia's rate of employment for its labor force is also higher (95.7 percent vs. 94.4 percent for the State). The vast majority of Volusia's workers work within the county ( 84.0 percent of all workers), with the City of Daytona Beach being the primary destination of these workers (29.5 percent of all workers). Inter-county work destinations include Seminole County, Orange County, and Flagler County, among others. The average commute time to work for Volusia County workers is 20.5 minutes, about a minute less than the 21.4 minutes that workers throughout Florida average. In addition, 55 percent of the workers in Volusia have commute times of less than 20 minutes (only 46.2 percent of Florida workers have similar travel times to work). Finally, the majority of workers in both Volusia County and Florida drive alone to work. When compared to all workers in Florida, Volusia County workers are just as likely to carpool and slightly less likely to use transit for their work trips.

\section{Summary of VOTRAN On-Board Survey Results}

The purpose of the on-board survey, conducted in February 2002, was to obtain information about customer demographics, travel behavior, and satisfaction with specific aspects of VOTRAN's fixed-route bus service. The information gathered as part of the on-board customer survey has many uses including planning or enhancing bus schedules, aiding in the location of new bus stops, modifying the existing multi-category fare structure, planning focused marketing campaigns and, in combination with other studies, identifying historical ridership trends and comparing these data with other transportation services in other areas of Florida. The resulting information from this survey becomes an invaluable tool in determining who is using VOTRAN service and why. A number of interesting findings were identified from the survey results.

\section{Customer Demographics}

- 54.2 percent of VOTRAN customers are between the ages of 25 to 54 years (median age for Volusia County is 42.4 years - 2001 Florida Statistical Abstract). 
- VOTRAN's ridership consists of a proportionally greater share of women (56.3 percent) than men (43.7 percent).

- The majority of VOTRAN ridership is composed of customers who indicated their ethnicity to be White ( 57.5 percent); 32.0 percent of customers indicated their ethnicity to be Black. Only 4.4 percent of VOTRAN's customers indicated being Hispanic.

- 51.9 percent of VOTRAN customers live in households with 2001 annual incomes of less than $\$ 15,000$. Additionally, 75.1 percent of VOTRAN customers have annual household incomes of less than $\$ 25,000$ (the median annual household income for Volusia County is $\$ 29,843$ - 2001 Florida Statistical Abstract).

- 7.8 percent of VOTRAN customers live in households with a reported annual income for 2001 of $\$ 50,000$ or more.

- 78.0 percent of VOTRAN customers do not have a car or other personal vehicle that they could have used to make the trip they took on transit.

- 85.3 percent of VOTRAN customers indicated being full-time residents of Volusia County.

- Based on the residential ZIP codes of VOTRAN customers, the bulk of VOTRAN's customer base resides within Daytona Beach, Port Orange, Holly Hill, South Daytona, Ormond Beach, Ponce Inlet, Deltona, DeLand, and New Smyrna Beach.

VOTRAN Customer Travel Behavior, Fare Usage, and Special Areas of Concerm

- 57.1 percent of VOTRAN customers began their trips at home and 15.0 percent began their trips at work.

- 29.6 percent of VOTRAN customers ended their trips at home and 26.8 percent ended their trips at work.

- The home-to-work (23.8 percent of all trip pairs) and work-to-home (10.7 percent) trip pairs dominate the travel of VOTRAN customers. Other proportionally frequent trip pairs include home-to-shopping/errands ( 9.3 percent), home-to-school (6.4 percent), and school-to-home (5.4 percent).

- 73.2 percent of VOTRAN customers walk four blocks or less to a bus stop in order to access transit service.

- 82.5 percent of VOTRAN customers walk four blocks or less to reach their final destination after alighting a bus.

- The proportion of VOTRAN customers using the bicycle as their principal mode of transit access (0.6 percent in 1999; 3.1 percent in 2002) and egress (0.7 percent in 1999; 3.5 percent in 2002) has increased since 1999, most probably due to the presence of bike racks on VOTRAN buses.

- 47.3 percent of VOTRAN customers have to make at least one transfer to complete their bus trips.

- The most utilized fare payment method among VOTRAN customers is the Adult Cash Fare of $\$ 1.00$ (54.0 percent).

- 18.3 percent of VOTRAN customers utilize the Monthly Value Pass (full-fare or discounted), which is higher than the use indicated in the 1999 survey for this type of pass (11.0 percent). 
- 67.6 percent of VOTRAN customers use the system five or more days per week.

- The majority of VOTRAN customers use the system for two primary reasons: they do not have a car available to them (36.2 percent) or they do not drive ( 33.8 percent).

- 31.9 percent of VOTRAN customers would rely on a friend or relative to give them a ride if they could not make their trip by transit.

- 16.2 percent of VOTRAN customers would not make their trip at all if VOTRAN were not available for their use.

- 22.0 percent of VOTRAN customers are relatively new to the system, having used it for six months or less (including first-time riders).

- 50.7 percent of VOTRAN customers get information about the system from bus schedules, and only 0.7 percent obtain information from newspapers, radio, or television, combined.

- 20.1 percent of VOTRAN customers indicated that they find it difficult to use VOTRAN's bus route and schedule information to plan their trips. Among the suggested improvements to make this information more user-friendly are making the maps more detailed with enhanced color coding of the routes; providing additional, more detailed information on streets and places in both the maps and schedules; and utilizing individual route maps and schedules for each route.

- 94.1 percent of VOTRAN customers would like to see the system provide later evening bus service.

- 46.2 percent of the customers desiring night bus service believe that the system should operate until midnight.

- 77.2 percent of the various suggested routes, roadways, and places that were suggested by VOTRAN customers as needing night bus service are located within the Eastside service area.

Based on the demographic characteristics and some of the travel behavior/trip characteristics, a typical VOTRAN customer profile was generated. The primary characteristics of the typical VOTRAN customer are:

- White female;

- Between the ages of 35 to 44 years;

- Has a total 2001 household income of less than $\$ 10,000$;

- Has no car or other personal vehicle to use to make her trip;

- Resides in Volusia County year round;

- Has been using VOTRAN for more than 4 years;

- Rides VOTRAN 5 days per week; and

- Rides VOTRAN because a car is not available.

Interestingly, these common traits of the typical VOTRAN customer are almost identical to those from the 1999 version of the on-board survey. 


\section{Customer Satisfaction}

- The most-liked aspect of using transit service, as noted by customers, was VOTRAN's bus drivers, followed by the ability to get where you want to go, the convenience of service, the economical nature of the service, and the opportunity to meet people and see friends.

- Aspects that were liked least by the customers included VOTRAN's limited service hours (i.e., no early morning/later evening service); trips taking too long too complete; other passengers on the bus when they are being loud, rude, inconsiderate, etc.; the bus drivers who are rude, inconsiderate, unhelpful, etc.; long wait times along with having to wait for the bus; and the relative infrequency of service, further exacerbating the long travel times.

- Based on average satisfaction ratings, VOTRAN customers are the most satisfied with the driving ability of the bus operators, the ease with which bus route and schedule information can be obtained, the value of the bus fare, and the personal safety/security they experience while riding the bus.

- The average satisfaction ratings indicated that VOTRAN customers are least satisfied with the hours of service on weekdays and weekend days (start and end times), the frequency of service, the amount of time it takes to make a trip by bus, and the number of transfers that must be made to complete a trip.

- Bus driver courtesy, the time of day the latest buses run on weekend days, and the time of day the latest buses run on weekdays were listed by VOTRAN customers as being the three most important service performance characteristics related to their use of transit service.

- A combined 74.9 percent of VOTRAN customers indicated being "very satisfied" or "satisfied" with VOTRAN service, overall. The overall average satisfaction rating for VOTRAN service is 4.11 out of a possible 5.00. These results indicate a decline from the overall satisfaction levels expressed in the 1999 survey, where a combined 84.5 percent of customers indicated being "very satisfied" or "satisfied" with VOTRAN service and the overall average satisfaction rating for VOTRAN service was 4.37 at that time.

The results from the 2002 survey of VOTRAN customers indicate that VOTRAN continues to provide a service that is a necessity to the majority of its customers. While many customers took advantage of the opportunity the survey afforded them to voice their complaints about the various aspects of VOTRAN service that they would like to see improve, the overall results indicate that the system's customers are satisfied with the service currently being offered by VOTRAN. Nevertheless, it would be in VOTRAN's best interest to look into the feasibility of addressing any or all of those areas for improvement that were noted by its customers. In particular, it is apparent that the issue of night bus service has gained prominence and a greater sense of immediacy in the minds of VOTRAN's customers since the last survey in 1999. With this in mind, it is expected that the customer survey results will be an important tool for VOTRAN management and staff to help guide any current and/or future attempts to improve various aspects of the system's services. 


\section{Summary of VOTRAN Operator Survey}

As part of the preparation of the TDP, a survey was prepared and given to the VOTRAN bus operators. Because the bus operators are in direct contact with the riders, they are an invaluable source of information concerning public opinion and attitude about VOTRAN's daily operation. The survey instrument addressed customer complaints, safety issues, service expansion, and allowed the operators to elaborate on those issues that they feel ought to be addressed by VOTRAN.

- As drivers are often the first to hear of complaints from passengers, they were asked to identify and rank the five most frequent complaints expressed by passengers. The most frequent passenger complaints identified by bus operators include the need for later evening service, that the bus schedules are hard to understand, and the need for more Sunday service.

- The most commonly-suggested improvements for VOTRAN as identified by bus operators include to add more Sunday service, provide better route/schedule information, and to give more time in the schedules. Many of the responding operators also agreed with passengers that more shelters are needed at bus stops and that buses should operate more frequently.

- The safety problem noted most often by bus operators is accomplishing turns without the aid of signalization. Other safety problems noted frequently include merging into traffic in congested conditions, trees or other objects obstructing the operators' view, and schedules being too tight, thereby requiring drivers to rush and drive more aggressively.

- According to bus operators, the schedule for Route 60 is the most difficult to maintain because there is not enough time built into the schedule. The second-most mentioned was Route 3.

- Bus operators were asked their opinions on the several route changes implemented by VOTRAN as a result of the 1999 Comprehensive Operations Analysis (COA) during the latter part of 2000. A majority of responding operators believe that the COA changes were beneficial. Those who did not feel the changes were beneficial made comments related to infrequent service, lack of passengers, and late buses.

- The vast majority of operators who responded to the survey believe that both night service and Sunday service are necessary.

\section{Summary of Interviews with Key Local Officials}

Interviews with key local officials and community leaders are recognized as a critical component of the transit development planning process. It is often these individuals who are directly responsible for proposing and funding transit policy. In an effort to gain insight regarding the officials' opinions about transit, VOTRAN, and its services, and at the recommendation of the TDP Review Committee, interviews were scheduled with Volusia County's seven County Council members, the County Manager, and other officials and community leaders. During March and April 2002, CUTR conducted 18 interviews. 
To summarize, the interview participants shared their candid opinions and perceptions regarding VOTRAN and transit in general. Overall, VOTRAN itself, its management, and its responsiveness to the community are perceived very well. Those interviewed believe VOTRAN does well at allocating its limited resources. When asked about the results of the COA route changes, the overall responses were positive; however, three issues arose regarding the underutilization of Route 24 serving Pierson, the "Cardinal Avenue problem," and a concern over the level of service provided to some schools on the Westside.

Improvements for VOTRAN suggested most often by the participants were the provision of night service and increased frequency of service. Other improvements are to provide more weekend services, use smaller buses whenever feasible, improve bus stop amenities, and improve community outreach efforts, including better route and schedule information. Whether supportive or not of the idea of commuter rail, several indicated that rail service will likely be coming to Volusia County in the near future and VOTRAN must be prepared to provide feeder services. No optimism was indicated for any new tax revenue to fund VOTTRAN services. Instead, participants believed VOTRAN should explore alternate means of funding for any improvements. As in the last major TDP update, the prevailing sentiment is toward increasingly efficient and effective transit services, i.e., maintaining or even improving services with the same amount of funding.

\section{Summary of Workshops}

Traditionally, conducting workshops with transit users as well as non-users provides highly useful information to a transit system. Users have the advantage of familiarity with the system and can offer much insight as to how the system is actually doing in its provision of transit service. In addition, non-users represent the potential riders of the system, and their perceptions and observations can provide insight into how the general public views the transit system. The sum of these opinions are important in that they offer the transit system suggestions for improving service that may ultimately help it retain current users and attract potential users. The workshops are intended to provide certain qualitative information regarding the transit system by facilitating open-ended discussions.

CUTR attended meetings of the following groups to hold informal workshops on public transportation in Volusia County:

- Transportation Disadvantaged Local Coordinating Board (TDLCB)

- Handicapped Adults of Volusia County (HAVOC)

- Southeast Volusia Senior Advisory Council

- MPO's Citizen Advisory Committee (CAC)

- FAITH (Fighting Against Injustice Toward Harmony) 
At the beginning of each workshop, introductions were made and participants were asked to share their opinions of public transit. Discussions focused on perceptions and awareness of public transportation in general and VOTRAN specifically. Overall, VOTRAN was praised for being attuned to the needs of the community and trying to be as responsive as it can given its resources.

Access to jobs was a topic that arose at most of these workshops. Participants in all workshops, including users and non-users, indicated a need for night bus services and increased frequency of service. Other improvements include better route/schedule information, better access to places in neighboring counties such as Orlando Airport, and better accessibility and amenities at fixed-route bus stops.

\section{CHAPTER TWO: GOALS AND OBJECTIVES}

The identification of goals and objectives for a transit system is a fundamental step in the development of a TDP. This chapter summarizes the policy issues identified in discussions that CUTR held with community leaders, the TDP Review Committee, VOTRAN and MPO staff, and various community groups and members of the public. The issues highlighted during these discussions form the basis for the proposed goals for VOTRAN. In addition, this list of goals was supplemented by an examination of existing transit-related policies assembled from the comprehensive plans for Volusia County and a number of municipalities within the County, as well as a survey of transit passengers. The proposed goals focus on five interrelated policy areas important to the effective operation of a transit system. These include:

- Availability, efficiency, and safety of service;

- Passenger amenities and marketing;

- Transportation planning coordination;

- Funding; and

- Public involvement process.

Table ES-1 presents the proposed goals along with their corresponding policy objectives. Each policy objective outlined in the table addresses, in a broad policy context, actions to be taken in order to achieve the stated goal. 


\section{Table ES-1 \\ VOTRAN Goals}

\begin{tabular}{|c|c|}
\hline $\begin{array}{c}\text { Goal } \\
1 \\
\end{array}$ & $\begin{array}{l}\text { Participate In and Ensure Availability of an Effective Public Transportation Systom that Safely and } \\
\text { Efficiently Moves People Throughout, In, and Out of Volusia County }\end{array}$ \\
\hline & $\begin{array}{l}\text { - Continue to operate as the mobility manager for Volusia County, operating/coordinating transit and } \\
\text { paratransit service, carpools, vanpools, and other TDM activities/strategies. } \\
\text { - Provide the safest possible transit service; include safety provisions for pedestrians, bicyclists, and } \\
\text { persons with disabilities at all transit facilities. } \\
\text { - Comply with all requirements of the Americans with Disabilities Act of } 1990 \text { (ADA); improve access to } \\
\text { - Optimsit for persons with disabilities. } \\
\text { current level of service or better throughout the area. } \\
\text { - Increase frequency of service on most congested corridors and busiest routes. } \\
\text { - Increase the span of service, specifically to include night service on routes based on need. } \\
\text { - Use appropriate-size vehicles, and develop flexible community bus routes to maximize ridership. } \\
\text { - Enhance Park-and-Ride program, express bus service, and the vanpool program. } \\
\text { - Maintain, improve, or expand service to major intermodal facilities, terminals, employment centers, } \\
\text { - Schools, activity centers, parks, recreational areas, cultural facilities, and social and medical facilities. } \\
\text { - Continue to monitor overall system performance as well as individual route performance. } \\
\text { - Mrovide a network of reasonable transit and paratransit connections to counties adjacent to Volusia. } \\
\text { - solutions. } \\
\text { - Explore the potential of rail modes for future use within the county and connecting to surrounding } \\
\text { counties. } \\
\text { - Continue to monitor ridership market through on-board surveys, customer satisfaction survevs, etc. }\end{array}$ \\
\hline \multirow[t]{2}{*}{$\begin{array}{c}\text { Goal } \\
2\end{array}$} & $\begin{array}{l}\text { Provide New and Maximize the Use of Existing Quality Passenger Amenities to Enhance Bus Service } \\
\text { and Attract Discretionary Riders }\end{array}$ \\
\hline & $\begin{array}{l}\text { - Provide more shelters/benches at highly used bus stops, transfer points, and other locations as } \\
\text { necessary. } \\
\text { - Work with the MPO and others to develop a standard for placement of bus stops, benches, and shelters } \\
\text { that can be implemented countywide. } \\
\text { - Install bicycle racks at those bus stops where heavy bicycle use has been noted. } \\
\text { - Explore feasibility of using Advanced Public Transportation System (APTS) Technology, such as smart } \\
\text { cards, to improve amenities for riders. } \\
\text { - Review the effectiveness and user-friendliness of current route and schedule information; make } \\
\text { improvements as necessary and ensure its availability to both current and potential system users. } \\
\text { - Continue community outreach/education programs for fixed-route and paratransit services. } \\
\text { - Maintain the VOTRAN bus stop inventory to assess the accessibility of existing stops and catalog existing } \\
\text { amenities (e.g., phones, lighting, shelters, benches, etc.) at each stop. } \\
\text { - Continue to increase the visibility of VOTRAN through creative marketing efforts. } \\
\text { - Continue to coordinate transit services with other transportation providers in and adjacent to Volusia } \\
\text { County. }\end{array}$ \\
\hline $\begin{array}{c}\text { Goal } \\
3\end{array}$ & $\begin{array}{l}\text { Coordinate the Transit System and Its Improvements with Transportation Planning Efforts of All } \\
\text { Government Entities }\end{array}$ \\
\hline & $\begin{array}{l}\text { - Initiate planning to provide service in projected growth areas of the county. } \\
\text { - Coordinate with local governments for the construction of accessible sidewalks, bus stops, and other bus } \\
\text { stop improvements along existing roadways. } \\
\text { - Continue to coordinate with state and local government and transportation agencies the integration of } \\
\text { transit needs/amenities into the land use planning and development process. } \\
\text { - Coordinate and encourage intermodal strategies that lessen dependency on single-occupant vehicles. } \\
\text { - Continue to ensure the coordination of all comprehensive plans and other related planning documents. } \\
\text { - Encourage local government to maintain higher densities near arterial and urban collector public } \\
\text { transportation corridors. } \\
\text { - Encourage local government to remove land-use barriers that may restrict the use of public transportation. } \\
\text { - Require developers to include public transportation-compatible designs in their projects (e.g., parking lot } \\
\text { requirements, bus shelters, bike facilities, etc.) } \\
\text { - Coordinate with the Florida Department of Transportation and agencies related with the 1-4 Master Plan } \\
\text { as it relates to rail service into, adjacent to, and within Volusia County. }\end{array}$ \\
\hline
\end{tabular}


Table ES-1 (continued)

VOTRAN Goals

\begin{tabular}{|c|c|}
\hline $\begin{array}{c}\text { Goal } \\
4\end{array}$ & $\begin{array}{l}\text { Provide a Transit System that is, to the Maximum Extent Possible, Financially Feasible by Securing } \\
\text { Adequate Funding }\end{array}$ \\
\hline & $\begin{array}{l}\text { - Maintain current Federal, State, and County funding sources for the fixed-route and paratransit systems. } \\
\text { - Identify and evaluate alternative funding sources for the fixed-route and paratransit systems. } \\
\text { - Secure a long-term dedicated funding source for the fixed-route and paratransit systems. } \\
\text { - Secure funding source for any future rail feeder service designed to link rail and intermodal facilities. } \\
\text { - Continue to expand bus pass program. } \\
\text { - Strive to develop, manage, operate, and maintain, to the maximum extent possible, a cost-feasible transit } \\
\text { system. } \\
\text { - Provide transit service that is, to the maximum extent possible, effective and efficient and is operated in a } \\
\text { fiscally-responsible manner. } \\
\text { - Evaluate appropriate technologies to enhance service delivery (e.g., scheduling, vehicle location, etc.) }\end{array}$ \\
\hline \multirow[t]{2}{*}{$\begin{array}{c}\text { Goal } \\
5 \\
\end{array}$} & Maintain a Proactive Public Involvement Process \\
\hline & $\begin{array}{l}\text { - Provide early and continuing opportunities for the public to express views that relate to transit services, } \\
\text { plans, and improvement programs and projects (e.g., surveys, grievance process, interviews, workshops, } \\
\text { etc.). } \\
\text { - Provide complete information about transit issues, adequate public notice of time and place, and full } \\
\text { public access to open public meetings where matters related to transit programs are being considered. } \\
\text { - Allow time for public review and comment at key decision points in the transit planning process. } \\
\text { - Utilize public and expert opinions about the overall quality and frequency of transit services in optimizing } \\
\text { fixed-route and paratransit services. } \\
\text { - Educate the community on the use of the public transportation system through the following methods: (a) } \\
\text { train the public how to use and/or access the system, (b) educate the public about misuses or abuses of } \\
\text { the transportation system, and (c) promote the one dollar tag contribution in support of the transportation } \\
\text { disadvantaged program. } \\
\text { - Continue to provide opportunities for public officials to be exposed to and educated about public } \\
\text { transportation and vOTRAN's services, in particular. } \\
\text { - Continue to utilize the Transportation Disadvantaged Local Coordinating Board and the MPO Citizens } \\
\text { Advisory Committee to assist in providing input to management on all aspects of service planning. }\end{array}$ \\
\hline
\end{tabular}

\section{CHAPTER THREE: PERFORMANCE EVALUATION OF FIXED-ROUTE TRANSIT SERVICE}

Chapter Three summarizes the results of the performance evaluation of Volusia County's existing fixed-route transit service, as provided by VOTRAN. The performance evaluation of VOTRAN's fixed-route service was conducted using two distinct analyses. The first method, the trend analysis, involves an examination of the system's performance over a six-year time period (FY 1996 through FY 2001). The second method of analysis is the peer review. This particular type of analysis compares the performance of VOTRAN with that of other selected Florida and non-Florida peer transit systems that are similar in system size, characteristics, and operating environment.

According to available information regarding VOTRAN's services, it is evident that the number of passenger trips VOTRAN carried on its directly-operated, fixed-route motorbus mode remained relatively stable (less than one percent decline) between 2000 and 2001 despite the route restructuring the system implemented in September 2000, as a result of the Comprehensive Operations Analysis (COA) that was completed as part of the 1999 TDP. 
Typically, significant route modification can result in rider indignation and confusion, which may alter travel behavior sufficiently to impact ridership levels in a negative fashion. This impact lessens over time as riders, both experienced and those newer to the system, become acclimated to the various changes (e.g., new transfer patterns, route access changes, etc.) and return to their previous transit utilization patterns. Additionally, it is expected that some of the route changes have resulted in fewer overall transfers, which would translate to fewer unlinked passenger trips.

A summary of VOTRAN's performance strengths and weaknesses based on the trend analysis is provided in Table ES-2. The intent of this table is not to suggest the extent of the strength or weakness but to identify those performance areas where the trend has improved or worsened from 1996 to 2001. A performance strength is defined as any performance area that improved or was maintained over the trend analysis time period. A performance weakness is defined as a trend that declined over the trend analysis time period.

Table ES-2

VOTRAN Performance Strengths and Weaknesses, Trend Analysis

\begin{tabular}{|c|c|}
\hline Performance Strengths & Performance Weaknesses \\
\hline $\begin{array}{c}\text { Labor Productivity (service supply) } \\
\text { Service Consumption }\end{array}$ & $\begin{array}{c}\text { Service Supply } \\
\text { Cost Efficlency } \\
\text { Farebox Recovery }\end{array}$ \\
& Labor Productivity (service consumption) \\
\hline
\end{tabular}

A summary of the fixed-route service's performance strengths and weaknesses based on the peer review analysis is provided in Table ES-3. A performance strength is defined as a performance area that is more than 10 percent better than the peer group average, while a performance weakness is defined as a performance area that is more than 10 percent worse than the peer group average.

Table ES-3

VOTRAN Performance Strengths and Weaknesses, Peer Review Analysis

\begin{tabular}{|c|c|}
\hline Performance Strengths & Performance Weaknesses \\
\hline Cost Efficiency & $\begin{array}{c}\text { Service Supply } \\
\text { Service Consumption } \\
\text { Farebox Recovery }\end{array}$ \\
\hline
\end{tabular}

Overall, VOTRAN continues to perform relatively well given its resources and the magnitude of the area which it has been tasked with serving. The system is outperforming the vast majority of its peers in most of the general performance indicators. Unfortunately, the system's service area size and population have significantly impacted its performance in a number of 
effectiveness and efficiency measures, most notably the per-capita ratios that measure service supply and consumption. However, VOTRAN's data indicate that the system's personnel continue to be efficiently productive and that the system is still comparatively cost efficient. And, recent improvements also have been noted in areas that have been problematic previously during the trend period, such as VOTRAN's average fleet age, which has declined significantly due to the purchase of new vehicles (thereby improving quality of service). Trend and peer review analyses such as these are useful in developing a better understanding of VOTRAN's performance and in identifying target areas for additional attention and improvement.

\section{CHAPTER FOUR: PERFORMANCE EVALUATION OF PARATRANSIT SERVICE}

This chapter reviews the performance of the demand-response/paratransit portion of VOTRAN's services. VOTRAN offers paratransit services in compliance with the Americans with Disabilities Act of 1990 (ADA). Individuals who are unable to use the fixed-route bus system may be eligible to receive service within $3 / 4$-mile of the fixed route. ADA eligibility is determined through a strict application process, requiring an in-person evaluation. Once an individual is deemed eligible, reservations must be made in advance to receive the door-to-door transportation.

The performance evaluation has two parts: a trend analysis and a peer review analysis. The trend analysis examines the system's performance over a multi-year time period from FY 1996 to FY 2001. Peer review compares the performance of VOTRAN with that of other selected Florida and non-Florida peer transit systems that are similar in system size, characteristics, and operating environment.

According to the trend analysis, the number of passenger trips for VOTRAN's directly-operated demand-response service increased. In many ways, an increase in the number of trips suggests that the service is needed and is being utilized. Conversely, an increase in trips might also suggest that VOTRAN could improve in the area of multi-loading and scheduling or that it could follow a more stringent ADA-eligibility process to encourage those capable of traveling on the fixed-route system to do so. It appears that, over the trend period, VOTRAN has successfully strengthened its ability to provide more trips without significant increases in employee resources. However, the increase in trips has not occurred without costs, due to the increase in vehicle miles and increase in the number of vehicles operated.

Data reported for peer demand-response systems can be difficult to understand and explain. Nine of the ten peer systems selected for this analysis purchased at least some of their trips; only one agency directly-operated all of their demand-response service. There is often more than one purchasing provider, making the reported data subject to interpretation. Given the nature of VOTRAN's service area, it is performing well in comparison to its demand-response peer group. VOTRAN demonstrates exceptional performance in the area of effectiveness, excelling in trips per capita and trips per revenue hour. 
Trend and peer group analysis can present different perspectives on identical data. Each has great utility as a tool in performance measurement; however, neither should be used as the only tool for making inferences about the quality of VOTRAN's paratransit services.

\section{CHAPTER FIVE: DEMAND ESTIMATION AND NEEDS ASSESSMENT}

In developing a five-year TDP for Volusia County, three important steps in the process include the preparation of estimates of demand for transit service over the five-year period, the assessment of mobility needs in the county, and an evaluation of alternate methods for increasing mobility through transit system improvements. This chapter summarizes the results of these efforts.

\section{Demand Estimates}

Various methods of estimating demand for both fixed-route transit and paratransit service and assessing unmet mobility needs are presented and discussed in this chapter. These techniques utilize the data and findings from all previous tasks. Transit service alternatives have been identified through the results of the workshops, interviews, on-board bus passenger survey, and operator survey, as well as through CUTR's experience in other urban areas similar in size to Volusia County.

There are several different methods available to estimate the level of demand for transit service in Volusia County. For example, the demand for fixed-route service may be estimated through the use of trend analysis, peer review comparisons among similar Florida and non-Florida transit systems, fare and service elasticities, census block group analysis, results of community leader interviews, and survey results. Table ES-4 shows the existing level of ridership (FY 2001) for VOTRAN and the estimated future ridership derived from a linear regression model for fiscal years 2002 through 2007. As the table shows, it is expected that, based on this model, the system's ridership will increase to approximately 4.29 million trips by 2007 , a seven percent increase from FY 2001, all else constant.

Table ES-4

Fixed-Route Ridership Projections for VOTRAN

(based on regression analysis)

\begin{tabular}{|c|c|c|c|c|c|c|c|}
\hline & FY 2001 & FY 2002 & FY 2003 & FY 2004 & FY 2005 & FY 2006 & FY 2007 \\
\hline Ridership' & $4,014,792$ & $3,700,000$ & $3,819,000$ & $3,938,000$ & $4,057,000$ & $4,175,000$ & $4,294,000$ \\
\hline
\end{tabular}

'Level of service, average fare, and other factors held constant.

It should be noted that using this methodology originally resulted in estimates too high for VOTRAN to reasonably reach, especially in the early years of the forecast. For example, the model predicted well over four million trips for FY 2002. This result does not mean that the 
regression model is not useful; rather, an adjustment needed to be made to account for ridership already occurring in FY 2002. In addition, VOTRAN is planning to eliminate special services for Daytona Speedway events in the near future, which will also reduce ridership. Hence, based on ridership numbers to date, it was estimated that VOTRAN could expect to reach approximately 3.7 million trips by the end of FY 2002. Then, the regression model was used to predict ridership starting in FY 2003, based on the 3.7 million trips estimated for FY 2002. Table ES 4 shows the ridership VOTRAN could achieve over the next five years, all else constant, based on historic ridership data.

Estimates of the demand for ADA complementary paratransit services were also developed for inclusion in this chapter. The methodology used is based on the ADA Paratransit Handbook prepared by the U.S. Department of Transportation. Demand estimates included in Table ES-5 represent a forecast of demand for ADA complementary paratransit over the next six years. These estimates are based on the assumption that ADA complementary paratransit utilization within Volusia County begins in $\mathbf{2 0 0 2}$ at the current rate of certification among the ADA-eligible population (72 percent), as reported by VOTRAN. Using this approach, the demand for ADA complementary paratransit can be expected to diminish from 302,946 (actual) trips in 2001 to 217,730 (estimated) in 2007.

Table ES-5

ADA Demand Estimates

\begin{tabular}{|l|c|c|c|c|c|c|c|}
\hline & FY 2001 & FY 2002 & FY 2003 & FY 2004 & FY 2005 & FY 2006 & FY 2007 \\
\hline $\begin{array}{l}\text { Eligibility } \\
\text { Estimates }\end{array}$ & 6,727 & 6,804 & 6,882 & 6,961 & 7,041 & 7,122 & 7,204 \\
\hline $\begin{array}{l}\text { Percent } \\
\text { Registered }\end{array}$ & $73 \%$ & $69 \%$ & $65 \%$ & $61 \%$ & $57 \%$ & $53 \%$ & $49 \%$ \\
\hline $\begin{array}{l}\text { Number } \\
\text { Registered }\end{array}$ & $4,912^{1}$ & 4,695 & 4,473 & 4,246 & 4,013 & 3,775 & 3,530 \\
\hline $\begin{array}{l}\text { Annual } \\
\text { Estimated } \\
\text { Trips }\end{array}$ & $302,946^{\prime}$ & 289,588 & 275,895 & 261,893 & 247,522 & 232,842 & 217,730 \\
\hline
\end{tabular}

${ }^{1}$ Actual for 2001

\section{Needs Assessment}

\section{Fixed-Route Service}

The comparison of demand estimates with existing transit service provides the basis for an assessment of unmet transit needs, along with the consideration of existing perceptions of the transit system and of the goals and objectives developed for VOTRAN. The concept of "unmet demand" can be interpreted in more than one way. It can mean those persons who use transit today but are not able to do so for all of their travel needs. It can also be viewed more broadly 
to include those persons who do not currently use the transit system but who might be induced to become riders through various changes to the system. A major focus in this needs assessment is the first group, because the mobility issue is more critical for these individuals. The latter group of potential riders must also be addressed in any needs assessment, since they comprise the most promising market for future transit growth. Based upon the system goals and objectives, demand estimates, and the findings from previous tasks, the following mobilityrelated needs have been identified. These are not listed in priority order.

- Later evening service

- Improved frequency

- Expanded weekend service

- Service coverage

- Bus stop amenities and related infrastructure

- Review of system schedules, maps, and other information

- Additional express service

- 1999 Comprehensive Operations Analysis (COA) review

- Coordination/interaction with local governments and other agencies

- Linkage to Orlando/LYNX

- Improved community relations and marketing activities

- Transit education programs

- Source for long-term funding

- Coordination with rail service

\section{Paratransit Service}

Similar to that conducted for VOTRAN's fixed-route service, the following mobility needs have been identified for the system's paratransit service. Again, note that these are not listed in priority order.

- Use a strict certification process for ADA eligibility

- Maximize fixed-route bus system usage

- Provide additional training opportunities for contracted operators

\section{CHAPTER SIX: TRANSIT ALTERNATIVES AND RECOMMENDATIONS}

At this point in the TDP process, the focus shifts from a descriptive, analytical approach to a future-oriented perspective. The findings presented earlier are now brought together and used to develop alternatives for VOTRAN and to make recommendations for transit improvements in Volusia County. The first section of this chapter presents a selection of available transit service alternatives as well as a discussion of broad alternatives for VOTRAN's future direction over the next five years. From these, then, the most reasonable and promising alternatives are selected 
to form the basis of VOTRAN's vision for transit. To help achieve this vision and the agency's proposed goals and objectives, the next section develops a series of recommendations to be implemented over the next five years. The recommendations are prioritized according to the time frame for action: within the next year, within two-to-three years, and within four-to-five years. The final section estimates the costs associated with each recommendation.

\section{Future Direction for VOTRAN}

The peer review results and public input obtained through interviews, workshops, and surveys indicate that VOTRAN is well-positioned to move into the future. As discussed in previous sections, VOTRAN's performance, for the most part, compared favorably to that of its peers. There is a stable, knowledgeable management team in place. There also appears to be an increased awareness regarding the role that the public transit system can potentially play in meeting the challenges posed by Volusia County's growth. Areas where growth is concentrated are obvious candidates for expanded routes. In the immediate future, improvements such as increased frequency, enhanced amenities, and the extension of the time span of service to the evening hours can be considered for the core areas of the transit system, i.e., those routes that are most heavily traveled.

Primary needs identified by the public and local officials are in the areas of service improvements, including evening services and increased service frequency, userfriendly system information, community relations, bus stop amenities, and the provision of feeder service for any commuter rail operation. Because VOTRAN provides beneficial and necessary services, it is vital to ensure the availability of easy-to-use system information throughout the county, so that residents and visitors will know how, when, and where to access these services. Community relations and other marketing actions are also appropriate to help improve public awareness and perceptions of the transit system. These actions can benefit both the transit-dependent and discretionary riders and can encourage additional ridership.

Along with any efforts to inform/educate the public and current and potential customers, actions should be undertaken to improve the existing transit system. Reliability does not appear to be a problem, but there is an identified desire for more frequent and later transit service. Ensuring the accessibility of bus stops and the availability of upgraded amenities for transit riders (e.g., benches, shelters, information displays, etc.) is also a priority. Another important area of attention involves the possibility of new commuter rail service in the area. VOTRAN must prepare to provide feeder service to any commuter rail operation. Finally, service expansion should be focused in areas where significant transportation needs exist and where growth is occurring. For example, growth in the county is expected to continue in the southwest and to the west of and adjacent to the core beach area along the 1-95 corridor. VOTRAN should be prepared to respond to these changes. 
In summary, the most promising future direction for VOTRAN is to focus immediate attention on its core service and areas of significant need, and then to expand selectively in response to population and employment shifts. In addition, VOTRAN must follow and respond to developments regarding the implementation of commuter rail service in the area. This strategy allows VOTRAN to continue to serve its transit-dependent ridership while taking advantage of opportunities to attract new riders to public transportation.

\section{Five-Year Transit Development Plan: Findings and Recommendations}

Following is a summary of the recommendations developed for VOTRAN that should be implemented over the next five years. Recommendations are prioritized by time frame for implementation: within the next year, over the next two-to-three years, and over the next four-tofive years. Most of the recommendations fall into the near-term time frames, and it is expected that the transit development plan will be updated annually to account for changing conditions in Volusia County. Within each time frame, recommendations with a higher priority are generally listed earlier, but related actions are grouped as appropriate. Thus, the numbering scheme of the recommendations is not strictly in priority order.

Actions to be Initiated Within the Next Year

\section{Fixed-Route Service}

1. Pursue the establishment of a long-term dedicated funding source for VOTRAN.

2. Respond to Comprehensive Operations Analysis-recommended enhancements to the VOTRAN fixed-route bus system.

3. Ensure the availability of user-friendly, bilingual transit marketing information.

4. Continue to work towards establishing a countywide policy for the installation of bus shelters and benches.

5. Maintain and utilize bus stop inventory.

6. Continue to install bus shelters and amenities at key bus stop locations.

7. Install bicycle racks at bus stops and transfer points, as necessary.

8. Continue to monitor all technology advancements applicable to public transportation.

9. Continue to develop and implement superstops, as prioritized. 
10. Continue to work with other Government agencies to achieve better accessibility to bus stops.

11. Continue the vehicle replacement program and purchase new expansion vehicles for fixedroute and paratransit services.

12. Continue to track the performance of individual routes via VOTRAN's formal route monitoring program.

13. Maintain VOTRAN's involvement in the transportation planning process.

14. Continue to encourage public input through interaction with local advisory/advocacy groups and committees.

15. Strive to ensure that all municipalities recognize and support VOTRAN's involvement as a review agency in the local land use planning process.

16. Establish an interlocal agreement between LYNX and VOTRAN that defines the level of support and participation, including operational costs, for the Commuter Rail Demonstration Program.

17. Continue to operate commuter express bus service (i.e., 1-4 Express Link) to Downtown Orlando if state funding can be secured and HOV lanes are constructed.

18. Continue to address the mobility needs of Volusia County residents, particularly those in transit-dependent and/or growth areas, as is financially feasible.

19. Continue to capitalize preventative maintenance activities, as necessary.

20. Continue the replacement or purchase of associated maintenance equipment and shop tools, as necessary.

21. Continue the replacement or purchase of associated office equipment, as necessary.

22. Continue the replacement or purchase of associated computer software, as necessary.

23. Continue the replacement or purchase of capital items related to facility renovation, as necessary.

24. Continue to replace service vehicles, as necessary. 
25. Continue the vehicle replacement program and purchase new expansion vehicles for the Vanpool Program.

26. Continue to use specially-painted buses to market transit.

27. Increase span of service (to provide later evening service) on selected core routes.

\section{Paratransit Service}

28. Continue to seek dedicated sources of funding to minimize the prioritization of TD nonsponsored trips.

29. Continue to educate customers on VOTRAN's service policies, such as pick-up windows.

30. Continue to provide additional training opportunities for contracted operator drivers and monitor the training provided by the contractors.

31. Continue to maximize the use of the fixed-route bus system. VOTRAN currently has a bus pass program for Medicaid clients.

Actions to be Initiated over the Next Two-to-Three Years

\section{Fixed-Route Service}

32. Increase frequency of service in US 1 corridor.

33. Implement more frequent service on the Beach Trolley.

34. Develop and implement a series of transit education programs.

35. Implement Saturday service on the Route 60 East-West Connector.

36. Continue to seek to improve the frequency of VOTRAN's busiest routes.

37. Implement more frequent service on the Route 60 East-West Connector.

38. Upgrade current farebox system to accept magnetic fare media.

39. Implement a VOTRAN all-day fare pass.

40. Increase level of Sunday service. 
41. Ensure consistency with Local Comprehensive Plan Transportation Element.

42. Develop feeder service to support the Commuter Rail Demonstration Program.

43. Develop and initiate activities to generate more tourist ridership.

44. Coordinate with the institutions of higher learning in Volusia County to establish an unlimited access agreement for students and staff.

\section{Paratransit Service}

45. Revise private operator contracts to allow for contract amendments based on changes to local service standards.

46. Revise provider contracts to require all newly purchased vehicles and those purchased after the effective date of the contract to have standard lifts with transit-style doors.

Actions to be Initiated over the Next Four-to-Five Years

\section{Fixed-Route Service}

47. Provide greater transportation linkage between the municipalities in Volusia County and the Orlando area.

48. Begin planning additional express bus service along major corridors and between distinct service areas in the county.

\section{Five-Year Transit Development Plan: Financial Plan}

Up to this point, the TDP process has not been constrained by fiscal considerations, in accordance with its strategic intent. Demographics, survey results, community input in various forms, and peer and trend analyses have all been used to assess the demand for transit service and to identify mobility needs in Volusia County. The recommendations presented herein have been based on previous findings and future directions. The final step in the transit development plan process is to estimate costs for these recommendations and compare them against current and anticipated financial resources.

Table ES-6 presents the most recent five-year budget estimate prepared by VOTRAN. The budget assumes that there is no increase in the amount of local tax funds that VOTRAN will receive over the next five years. 
Tables ES-7 and ES-8 present the costs associated with the funded and unfunded recommendations, respectively, and the projected dates of implementation. These costs are based on several assumptions for items, ranging from unit cost per bus shelter to the average cost per revenue mile (or revenue hour) for route modifications. These are the most reasonable assumptions available, but cost estimates should be refined at the time the recommendations are implemented, when greater detail will be available. Tables ES-9 and ES-10 present the capital and operating costs of the funded and unfunded recommended projects, respectively, by the fiscal year of implementation. Tables ES-11 and ES-12, then, present each project's operating and capital costs, respectively, distributed among the potential funding sources for each.

Finally, Table ES-13 compiles the data from the previous tables and presents a summary of VOTRAN's additional funding needs for the TDP's five-year time frame based on its existing operating and capital costs, as well as the costs associated with the TDP's unfunded recommendations. It should be noted that VOTRAN is currently operating under a constrained budget. Thus, priorities must be revised based on fiscal constraints, or potential new funding sources must be identified for implementation of the recommendations. 
Table ES-6

VOTRAN Five-Year Plan, 2003-2007 No Extra Service Over Present ${ }^{1}$

\begin{tabular}{|c|c|c|c|c|c|}
\hline & FYO2-03 & FY03-04 & FY04-05 & FY05-06 & FYO6-07 \\
\hline EXPENDITURES & $\$ 13,154,734$ & $\$ 13,680,923$ & $\$ 14,228,160$ & $\$ 14,797,287$ & $\$ 15,389,178$ \\
\hline Gold Ridership Increase & $\$ \quad 201,376$ & \$ 209,431 & \$ 217.808 & $\$ \quad 226,521$ & $\$ 235,581$ \\
\hline Reserve for claims \& W/C & $\$ \quad 645,000$ & $\$ 645,000$ & \$ 645,000 & $\$ 645,000$ & $\$ \quad 645,000$ \\
\hline Total Expenses & $\$ 14,001,110$ & $\$ 14,535,354$ & $\$ 15,090,969$ & $\$ 15,668,808$ & $\$ 16,269,759$ \\
\hline \multicolumn{6}{|l|}{ REVENUES } \\
\hline \multicolumn{6}{|l|}{ Operating Revenues } \\
\hline Fareboxes & $\$ 1,727,460$ & $\$ 1,779,284$ & $\$ 1,832,662$ & $\$ 1,887,642$ & \$ $1,944,271$ \\
\hline ADA Revenue & $\$ \quad 27,776$ & $\$ \quad 28,887$ & $\$ \quad 30,042$ & 31,244 & 32.494 \\
\hline Advertising & \$ $\quad 88,750$ & 95,000 & $\$ 110,000$ & \$ 115,000 & $\$ 120,000$ \\
\hline Service Contracts & \$ 385,147 & $\$ 385,147$ & S 385,147 & \$ 385,147 & $\$ 385.147$ \\
\hline Interest Revenues & $\$ 125,000$ & $\$ 125,000$ & \$ 125,000 & $\$ 125,000$ & $\$ 125,000$ \\
\hline Misc. Revenues & $\$ \quad 6,066$ & 6,066 & 6,066 & 6,066 & 6,066 \\
\hline Total Operating Revenues & $\$ 2,360,199$ & $\$ 2,419,384$ & $\$ 2,488,917$ & $\$ 2,550,099$ & $\$ 2,612,978$ \\
\hline Federal Funds & $\$ 96,984$ & \$ 96,984 & $\$ 96,984$ & $\$ \quad 96,984$ & \$ 96,984 \\
\hline Federal Maintenance Funds & $\$ 1,217,406$ & $\$ 1,380,849$ & $\$ 1,449,891$ & $\$ 1,522,335$ & $\$ 1,598,452$ \\
\hline State Block Grant & $\$ 1,874,250$ & $\$ 1,865,131$ & $\$ 1,890,681$ & $\$ 1,965,574$ & $\$ 2,043,514$ \\
\hline Section 5311 & $\$ 172,785$ & s 172,785 & \$ 172,785 & \$ 172,785 & $\$ 172,785$ \\
\hline Section $5311 f$ & $\$ \quad 86,360$ & 86,360 & 86,360 & 86,360 & 86,360 \\
\hline Other State Funds & $\$ \quad 80,560$ & $\$ 80,560$ & 80,560 & 80,560 & $\$ \quad 80,560$ \\
\hline T. D. Funds & $\$ 662,329$ & $\$ 675,072$ & $\$ 680,439$ & $\$ 692,580$ & s 708,227 \\
\hline Gas Tax Funds & $\$ 1,050,000$ & $\$ 1,050,000$ & $\$ 1,050,000$ & $\$ 1,050,000$ & $\$ 1,050,000$ \\
\hline Local Tax Funds & $\$ 4,452,080$ & $\$ 4,452,080$ & $\$ 4,452,080$ & $\$ 4,452,080$ & $\$ 4,452,080$ \\
\hline Medicaid & $\$ 1,303,157$ & $\$ 1,303,157$ & $\$ 1,303,157$ & $\$ 1,303,157$ & $\$ 1,303,157$ \\
\hline Total Revenues & $\$ 13,356,110$ & $\$ 13,582,362$ & $\$ 13,751,854$ & $\$ 13,972,514$ & $\$ 14,205,097$ \\
\hline Net Funds Available & $(\$ 645,000)$ & (\$ 952,992 ) & (\$ 1,339,114) & $(\$ 1,696,294)$ & (\$ 2,064,662) \\
\hline Prior Year Carry Forward & \$ 645,000 & $\$ 645,000$ & $\$ 645,000$ & $\$ 645,000$ & $\$ 645,000$ \\
\hline Net Carry Forward & $\$$ & $\mathbf{s}$ & $\$$ & $\$$ & $\$$ \\
\hline Unfunded Service & $\$$ & \$ 307,992 & $\$ \quad 694,114$ & $\$ 1,051,294$ & S $1,419,662$ \\
\hline Property Value & $\$ 18,761,231,446$ & $\$ 19,089,552,996$ & $\$ 19,423,620,174$ & $\$ 19,763,533,527$ & $\$ 20,109,395,363$ \\
\hline Rollback Tax Rate & 0.000237 & 0.000233 & 0.000229 & 0.000225 & 0.000221 \\
\hline Increase to Tax Rate & - & 0.000016 & 0.000036 & 0.000053 & 0.000071 \\
\hline TOTAL TAX RATE & 0.000237 & 0.000249 & 0.000265 & 0.000278 & 0.000292 \\
\hline BASE FARE & $\$ 1.00$ & $\$ 1.00$ & $\$ 1.00$ & $\$ 1,00$ & $\$ 1,00$ \\
\hline
\end{tabular}

'Assumes that there is no increase in the amount of local tax funds received by VOTRAN. 
Table ES-7

VOTRAN Transit Development Plan

Estimated Costs of Funded Recommendations ${ }^{1}$

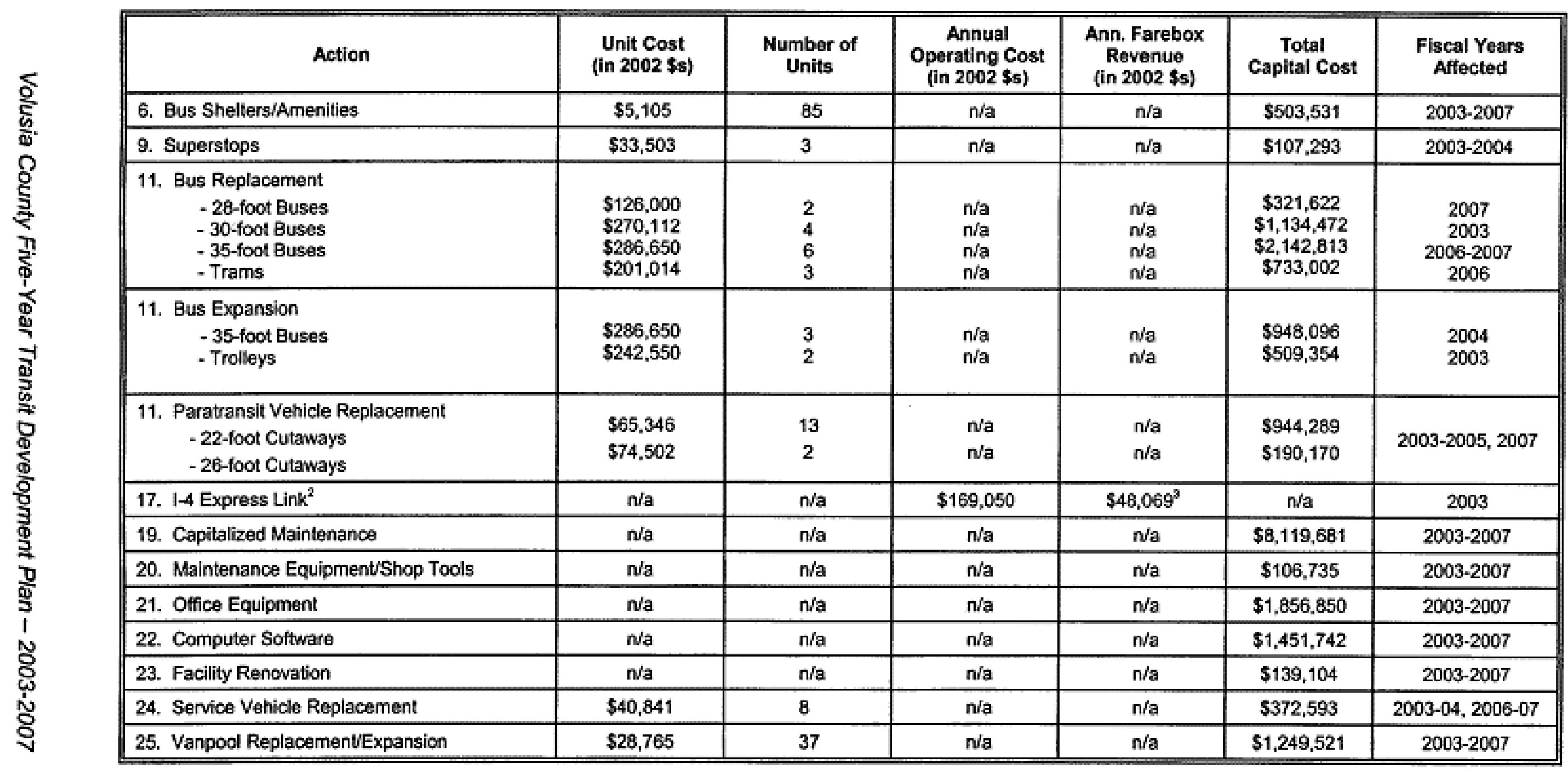

'Unless otherwise noted, information in this table is from VOTRAN's Capital Improvement Program.

${ }^{2}$ Annual operating cost for the 1-4 Express Link provided by VOTRAN.

${ }^{3}$ Annual farebox revenue for the 1-4 Express Link based on FY 2001 fare revenues for this route. 
Table ES-8

VOTRAN Transit Development Plan

Estimated Costs of Unfunded Recommendations

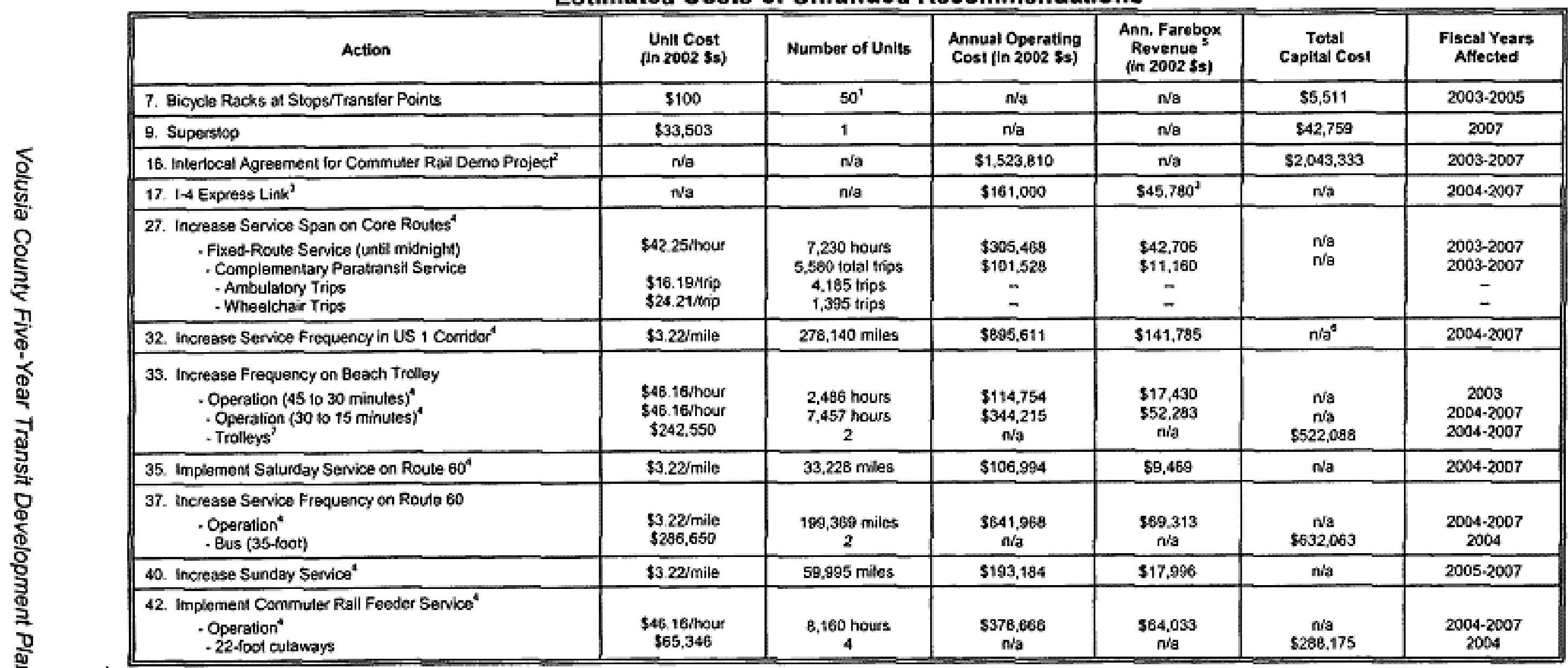

'Each unit holds two bicycles.

${ }^{2}$ Cosis related to interlocal agreement provided by VOTRAN.

3Annual operating cost provided by VOTRAN: annual farebox revenue based on FY 2001 fare revenues for this route.

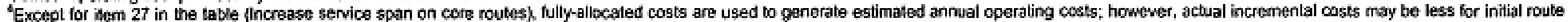
expansion.

"Farebox revenue for trequency increases is based an $61 \%$ of the systemwide FY 2001 farebox secovery rafio (service elasticity of 0.61). Farebox revienue for evenning and weekend service improvements is based on 50\% of the systemwide FY 2001 farebox recovery ratio. Farebox revenue for new feeder servico is based on the FY 2001 farebox recovery rato.

${ }^{\circ}$ Funding (FTA 5307) is available in 2004 for the three 35-foot buses required to operale this service frequency increase (see Table 2).

'Funding (FTA 5307) is avaitabte in 2003 for the two of the four trolleys required to operats this service frequency increase (see Table 2) 
Table ES-9

VOTRAN Transit Development Plan

Estimated Operating and Capital Costs of Funded Recommendations by Fiscal Year ${ }^{1}$

\begin{tabular}{|c|c|c|c|c|c|c|c|c|c|c|c|c|}
\hline \multirow[t]{2}{*}{ Action } & \multicolumn{2}{|c|}{ FY 2003} & \multicolumn{2}{|c|}{ FY 2004} & \multicolumn{2}{|c|}{ FY 2005} & \multicolumn{2}{|c|}{ FY 2006} & \multicolumn{2}{|c|}{ FY 2007} & \multicolumn{2}{|c|}{ Total FY 2003 - FY 2007} \\
\hline & $\begin{array}{l}\text { Operaling } \\
\text { Cost }\end{array}$ & $\begin{array}{c}\text { Capital } \\
\text { Cost }\end{array}$ & $\begin{array}{l}\text { Operating } \\
\text { Cost }\end{array}$ & $\begin{array}{l}\text { Capilal } \\
\text { Cosi }\end{array}$ & $\begin{array}{l}\text { Operating } \\
\text { Cost }\end{array}$ & $\begin{array}{l}\text { Capital } \\
\text { Cost }\end{array}$ & $\begin{array}{l}\text { Operating } \\
\text { Cost }\end{array}$ & $\begin{array}{l}\text { Capital } \\
\text { Cost }\end{array}$ & $\begin{array}{l}\text { Operating } \\
\text { Cost }\end{array}$ & $\begin{array}{l}\text { Capital } \\
\text { Cost }\end{array}$ & $\begin{array}{l}\text { Operating } \\
\text { Cost }\end{array}$ & Capital Cost \\
\hline 6. Bus Shelters/Amenílies & $\$ 0$ & $\$ 91,126$ & \$o & $\$ 95,683$ & $\$ 0$ & $\$ 100,467$ & $\$ 0$ & $\$ 105,490$ & $\$ 0$ & $\$ 110,765$ & 50 & $\$ 503,531$ \\
\hline 9. Superstops & so & $\$ 70,356$ & \$o & $\$ 36,937$ & \$o & $\$ 0$ & so & so & $\$ 0$ & $\$ 42,759$ & $\$ 0$ & $\$ 150,053$ \\
\hline $\begin{array}{l}\text { 11. Bus Replacement } \\
\text { - 28-tool Buses } \\
\text { - 30-foot Buses } \\
\text { - 35.foot Buses } \\
\text { - Trams } \\
\end{array}$ & $\begin{array}{l}\$ 0 \\
\$ 0 \\
\$ 0 \\
\$ 0\end{array}$ & $\begin{array}{c}\$ 0 \\
\$ 1,134,472 \\
\$ 0 \\
\$ 0\end{array}$ & $\begin{array}{l}\$ 0 \\
\$ 0 \\
\$ 0 \\
\$ 0\end{array}$ & $\begin{array}{l}\$ 0 \\
\$ 0 \\
\$ 0 \\
\$ 0\end{array}$ & $\begin{array}{l}\$ 0 \\
\$ 0 \\
\$ 0 \\
\$ 0\end{array}$ & $\begin{array}{l}\text { \$o } \\
\$ 0 \\
\$ 0 \\
\$ 0 \\
\end{array}$ & $\begin{array}{l}\$ 0 \\
\$ 0 \\
\$ 0 \\
\$ 0\end{array}$ & $\begin{array}{c}\$ 0 \\
\$ 0 \\
\$ 1,045,275 \\
\$ 733.002 \\
\end{array}$ & $\begin{array}{l}\$ 0 \\
\$ 0 \\
\$ 0 \\
\$ 0\end{array}$ & $\begin{array}{c}\$ 321,622 \\
\$ 0 \\
\$ 1097,538 \\
\$ 0\end{array}$ & $\begin{array}{l}\$ 0 \\
\$ 0 \\
\$ 0 \\
\$ 0\end{array}$ & $\begin{array}{c}\$ 321,622 \\
\$ 1,134,472 \\
\$ 2,142,813 \\
\$ 733,002\end{array}$ \\
\hline \begin{tabular}{|c|}
11. Bus Expansion \\
-35-foot Buses \\
- Trolleys
\end{tabular} & $\begin{array}{l}\text { \$o } \\
\text { so }\end{array}$ & $\begin{array}{c}\$ 0 \\
\$ 509,354 \\
\end{array}$ & $\begin{array}{l}\$ 0 \\
\$ 0\end{array}$ & $\begin{array}{c}\$ 948,096 \\
\$ 0\end{array}$ & $\begin{array}{l}\text { \$0 } \\
\$ 0\end{array}$ & $\begin{array}{l}\$ 0 \\
\$ 0 \\
\end{array}$ & $\$ 0$ & $\begin{array}{l}\$ 0 \\
\$ 0\end{array}$ & $\begin{array}{l}\$ 0 \\
\$ 0\end{array}$ & $\begin{array}{l}\$ 0 \\
\$ 0\end{array}$ & $\begin{array}{l}\text { so } \\
\text { \$o }\end{array}$ & $\begin{array}{l}\$ 949,096 \\
\$ 509,354\end{array}$ \\
\hline $\begin{array}{l}\text { 11.Paratransit Vehicle Replacement } \\
-22 \text {-foot Cutaways } \\
-26-100 t \text { Cutaways }\end{array}$ & $\begin{array}{l}\text { \$o } \\
\text { \$o }\end{array}$ & $\begin{array}{c}\$ 205,839 \\
\$ 0\end{array}$ & $\begin{array}{l}\$ 0 \\
\$ 0\end{array}$ & $\begin{array}{c}\$ 360,219 \\
\$ 0\end{array}$ & $\begin{array}{l}\text { \$o } \\
\text { \$0 }\end{array}$ & $\begin{array}{c}\$ 378,230 \\
\$ 0\end{array}$ & $\begin{array}{l}\text { so } \\
\text { so }\end{array}$ & 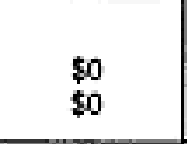 & 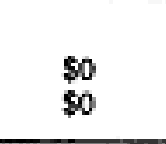 & $\begin{array}{c}\$ 0 \\
\$ 190,170\end{array}$ & $\begin{array}{l}\$ 0 \\
\$ 0\end{array}$ & $\begin{array}{l}\$ 944,299 \\
\$ 190,170\end{array}$ \\
\hline 17. 1-4 Express Link ${ }^{2}$ & $\$ 127,030$ & $\$ 0$ & $\$ 0$ & $\$ 0$ & $\$ 0$ & \$o & \$0 & $\$ 0$ & $\$ 0$ & $\$ 0$ & $\$ 127,030$ & $\$ 0$ \\
\hline 19. Capitalized Maintenance & $\$ 0$ & $\$ 1,455,099$ & $\$ 0$ & $\$ 1,562,521$ & $\$ 0$ & $\$ 1,658,205$ & $\$ 0$ & $\$ 1,672,051$ & so & $\$ 1,771,805$ & so & $\$ 8,119,681$ \\
\hline $\begin{array}{l}\text { 20. Maintenance EquigmentShop } \\
\text { Tools }\end{array}$ & $\$ 0$ & $\$ 12,078$ & $\$ 0$ & \$12,e91 & so & $\$ 13.315$ & so & $\$ 13,981$ & so & $\$ 54,680$ & $\$ 0$ & $\$ 106,735$ \\
\hline 21. Office Equipment & $\$ 0$ & $\$ 70,000$ & $\$ 0$ & $\$ 193,812$ & \$o & $\$ 1,200,318$ & $\$ 0$ & $\$ 332,720$ & $\$ 0$ & $\$ 60,000$ & $\$ 0$ & $\$ 1,856,850$ \\
\hline 22. Compuler Software & $\$ 0$ & $\$ 545,207$ & so & $\$ 267.452$ & $\$ 0$ & $\$ 300,000$ & 50 & $\$ 200,000$ & $\$ 0$ & $\$ 139,082$ & $\$ 0$ & $\$ 1,451,741$ \\
\hline 23. Facility Renovation & $\$ 0$ & $\$ 47,600$ & $\$ 0$ & $\$ 21,230$ & $\$ 0$ & $\$ 22,292$ & $\$ 0$ & $\$ 23,408$ & $\$ 0$ & $\$ 24,576$ & \$o & $\$ 139,104$ \\
\hline 24. Service Vehicle Replacement & $\$ 0$ & $\$ 128,469$ & \$o & $\$ 90,054$ & $\$ 0$ & $\$ 0$ & \$o & $\$ 49,642$ & $\$ 0$ & $\$ 104,249$ & so & $\$ 372,593$ \\
\hline $\begin{array}{l}\text { 25. Vanpool } \\
\text { ReplacementExpansion }\end{array}$ & so & $\$ 151,016$ & so & $\$ 253,707$ & so & $\$ 166,495$ & $\$ 0$ & $\$ 384,604$ & so & $\$ 293,698$ & so & $\$ 1,249,521$ \\
\hline Total by Fiscal Year & $\$ 127,030$ & $\$ 4,420,796$ & $\$ 0$ & $\$ 3,842,392$ & $\$ 0$ & $\$ 3,839.322$ & \$o & $\$ 4,560,171$ & 50 & $\$ 4,168,165$ & $\$ 127,030$ & $\$ 20,830,866$ \\
\hline
\end{tabular}

'Operating and capital costs are inflated at 5 percent per year.

${ }^{2}$ Bus service operating costs use fully-allocated system costs and are then reduced by projected fare revenues. Actual incremental costs may be less for initial route expansion.

Volusia County Five-Year Transit Development Plan - 2003-2007 
Table ES-10

VOTRAN Transit Development Plan

Estimated Operating and Capital Costs of Unfunded Recommendations by Fiscal Year ${ }^{1}$

\begin{tabular}{|c|c|c|c|c|c|c|c|c|c|c|c|c|}
\hline \multirow[b]{2}{*}{ Action } & \multicolumn{2}{|c|}{ FY 2003} & \multicolumn{2}{|c|}{ FY 2004} & \multicolumn{2}{|c|}{ FY 2005} & \multicolumn{2}{|c|}{ Fr 2006} & \multicolumn{2}{|c|}{ FY 2007} & \multicolumn{2}{|c|}{ Total FY 2003 - FY 2007} \\
\hline & $\begin{array}{l}\text { Operating } \\
\text { Cost }\end{array}$ & $\begin{array}{l}\text { Capital } \\
\text { Cost }\end{array}$ & $\begin{array}{l}\text { Operating } \\
\text { Cost }\end{array}$ & $\begin{array}{l}\text { Capital } \\
\text { Cost }\end{array}$ & $\begin{array}{l}\text { Operating } \\
\text { Cost }\end{array}$ & $\begin{array}{l}\text { Capltal } \\
\text { Cost }\end{array}$ & $\begin{array}{l}\text { Operating } \\
\text { Cost }\end{array}$ & $\begin{array}{l}\text { Capinal } \\
\text { Cost }\end{array}$ & $\begin{array}{l}\text { Operating } \\
\text { Cost }\end{array}$ & $\begin{array}{l}\text { Capital } \\
\text { Cost }\end{array}$ & $\begin{array}{c}\text { Operating } \\
\text { Cost }\end{array}$ & $\begin{array}{l}\text { Capital } \\
\text { Cost }\end{array}$ \\
\hline $\begin{array}{l}\text { 7. Bicycle Racks at Stops/Transfer } \\
\text { Points }\end{array}$ & $\$ 0$ & $\$ 1,785$ & $\$ 0$ & $\$ 1,874$ & $\$ 0$ & $\$ 1,852$ & $\$ 0$ & \$0 & $\$ 0$ & $\$ 0$ & $\$ 0$ & $\$ 5,511$ \\
\hline $\begin{array}{l}\text { 16. Interlocal Agreernent for } \\
\text { Commuter Rail Service }\end{array}$ & $\$ 1,600,000$ & $\$ 2,043,333$ & $\$ 1,680,000$ & so & $\$ 1,764,000$ & $\$ 0$ & $\$ 1,852,200$ & $\$ 0$ & $\$ 1,944,810$ & so & $\$ 8841,010$ & $\$ 2,043,333$ \\
\hline $\begin{array}{l}\text { 27. Increase Service Span on Core } \\
\text { Routes }\end{array}$ & $\$ 370,787$ & so & $\$ 389,326$ & $\$ 0$ & $\$ 409,792$ & $\$ 0$ & $\$ 429,232$ & $\$ 0$ & $\$ 450,693$ & \$o & $\$ 2,048.829$ & $\$ 0$ \\
\hline $\begin{array}{l}\text { 32. Increase Service Frequency in } \\
\text { us } 1 \text { Convidor" }\end{array}$ & $\$ 0$ & so & $\$ 931,093$ & \$o & $\$ 872,648$ & so & $\$ 916.280$ & so & $\$ 962.094$ & so & $\$ 3,582,115$ & $\$ 0$ \\
\hline $\begin{array}{l}\text { 33. Increase Frequency on Beach } \\
\text { Trolley }\end{array}$ & $\$ 102,190$ & $\$ 254,677$ & $\$ 321,855$ & $\$ 267,411$ & $\$ 337,948$ & $\$ 0$ & $\$ 354,845$ & so & $\$ 372.587$ & \$o & $\$ 1.489 .426$ & $\$ 522,098$ \\
\hline $\begin{array}{l}\text { 35. Implement Saturday Service on } \\
\text { Route } 60^{4}\end{array}$ & $\$ 0$ & $\$ 0$ & $\$ 107,521$ & \$o & $\$ 112,897$ & $\$ 0$ & $\$ 118,542$ & so & $\$ 124,469$ & $\$ 0$ & $\$ 463,430$ & $\$ 0$ \\
\hline $\begin{array}{l}\text { 37. Increase Service Frequency on } \\
\text { Route } 60\end{array}$ & so & $\$ 0$ & $\$ 631,352$ & $\$ 632.063$ & $\$ \$ 62,920$ & \$o & $\$ 696,066$ & \$o & $\$ 730,869$ & so & $\$ 2,721,207$ & $\$ 632,063$ \\
\hline 40. Increase Sunday Service & $\$ 0$ & so & \$o & so & $\$ 202,837$ & so & $\$ 212,979$ & $\$ 0$ & $\$ 223,628$ & \$o & $\$ 639,443$ & $\$ 0$ \\
\hline $\begin{array}{l}\text { 42. Implemem Commuler Rail } \\
\text { Feeder Service }\end{array}$ & $\$ 0$ & so & $\$ 376,654$ & $\$ 288.175$ & $\$ 395,486$ & so & $\$ 415.261$ & so & $\$ 436.024$ & $\$ 0$ & $\$ 1,623,424$ & $\$ 28 \mathrm{~B}, 175$ \\
\hline Total by Flscal Year & $\$ 2,072,977$ & $\$ 229,795$ & $\$ 4,337,800$ & $\$ 1,189,523$ & $\$ 4,757,528$ & $\$ 1,852$ & $\$ 4,995,405$ & so & $\$ 5,245,174$ & $\$ 42,759$ & $521,408,885$ & $\$ 3,533,929$ \\
\hline
\end{tabular}

${ }^{1}$ Operating and capital costs are inflated at 5 percent per year.

'Bus service operating costs use fully-allocated system costs and are then reduced by projected fare revenues. Actual incremental costs may be less for initial route expansion.

${ }^{3}$ Funding (FTA 5307 and/or STP) is available for a portion of the capilal costs for these recommendations in selected years.

"Except for item 27 in the table, (increase service span on core routes). full-allocated costs are used to generate estimated annual operating costs; however, actual incremental costs may be less for initial route expansion. 
Table ES-11

VOTRAN Transit Development Plan

Distribution of Estimated Operating Costs of Recommendations Among Potential Funding Sources by Fiscal Year ${ }^{1}$

\begin{tabular}{|c|c|c|c|c|c|c|}
\hline Action & FY 2003 & FY 2004 & FY 2005 & FY 2006 & FY 2007 & TOTAL \\
\hline $\begin{array}{l}\text { 16. Interlocal Agreement for Commuter Rail Demo Project } \\
\text { Unfunded Local (100\%) - FY 03-07 }\end{array}$ & $\$ 1,600,000$ & $\$ 1,680,000$ & $\$ 1,764,000$ & $\$ 1,852.200$ & $\$ 1,944,810$ & $\$ 8,841,010$ \\
\hline $\begin{array}{l}\text { 17. I-4 Express Link } \\
\text { FDOT Service Development }(50 \%)-\text { FY } 03 \\
\text { LOCal }(50 \%)-F Y 03\end{array}$ & $\begin{array}{l}\$ 63,515 \\
\$ 63,515 \\
\end{array}$ & $\begin{array}{l}\$ 0 \\
\$ 0\end{array}$ & $\begin{array}{l}\$ 0 \\
\$ 0\end{array}$ & $\begin{array}{l}\$ 0 \\
\$ 0\end{array}$ & $\begin{array}{l}\$ 0 \\
\$ 0\end{array}$ & $\begin{array}{l}\$ 0 \\
\$ 0\end{array}$ \\
\hline $\begin{array}{l}\text { 27. Increase Service Span on Core Routes } \\
\text { Candidate FDOT Service Development (50\%) - FY 03-04 } \\
\text { Unfunded Local (50\%) FY O3-04 } \\
\text { Unfunded Local (50\%) - FY 05-07 }\end{array}$ & $\begin{array}{l}\$ 185,394 \\
\$ 185,394 \\
\$ 0\end{array}$ & $\begin{array}{l}\$ 194,663 \\
\$ 194,663 \\
\$ 0\end{array}$ & $\begin{array}{c}\$ 0 \\
\$ 0 \\
\$ 408,792\end{array}$ & $\begin{array}{c}\$ 0 \\
\$ 0 \\
\$ 429,232\end{array}$ & $\begin{array}{c}\$ 0 \\
\$ 0 \\
\$ 450,693\end{array}$ & $\begin{array}{c}\$ 380,057 \\
\$ 380,057 \\
\$ 1,288,717\end{array}$ \\
\hline $\begin{array}{l}\text { 32. Increase Frequency of Service in US 1 Corridor } \\
\text { Unfunded Local }(100 \%)\end{array}$ & $\$ 0$ & $\$ 831,093$ & $\$ 872,648$ & $\$ 916,280$ & $\$ 962,094$ & $\$ 3,582,115$ \\
\hline $\begin{array}{l}\text { 33. Increase Frequency on Beach Trolley } \\
\text { Unfunded Local (100\%) }\end{array}$ & $\$ 102,190$ & $\$ 321,855$ & $\$ 337,949$ & $\$ 354,845$ & $\$ 372,597$ & $\$ \$ 1,489,425$ \\
\hline $\begin{array}{l}\text { 35. Implement Saturday Service on Route } 60 \\
\text { Unfunded Lccal (100\%) }\end{array}$ & $\$ 0$ & $\$ 107,251$ & $\$ 112,897$ & $\$ 118,542$ & $\$ 124,469$ & $\$ 463,429$ \\
\hline $\begin{array}{l}\text { 37. Increase Service Frequency on Route } 60 \\
\text { Unfunded Local (100\%) }\end{array}$ & $\$ 0$ & $\$ 631,352$ & $\$ 662,920$ & $\$ 696,066$ & $\$ 730,869$ & $\$ 2,721,207$ \\
\hline $\begin{array}{l}\text { 40. Increase Sunday Service } \\
\text { Unfunded Lccal }(100 \%)\end{array}$ & $\$ 0$ & So & $\$ 202,837$ & $\$ 212,979$ & $\$ 223,628$ & $\$ \$ 639,444$ \\
\hline $\begin{array}{l}\text { 42. Implement Commeter Rail Feeder Service } \\
\text { Unfunded Local (100\%) }\end{array}$ & $\$ 0$ & $\$ 376,654$ & $\$ 395,486$ & $\$ 415,261$ & $\$ 436,024$ & $\$ 1,623,425$ \\
\hline $\begin{array}{l}\text { Funded Operating Costs } \\
\text { FDOT Service Development } \\
\text { Local } \\
\text { Subtotal [Funded Revenues] }\end{array}$ & $\begin{array}{l}\$ 63,515 \\
\$ 63,515 \\
\$ 127,030\end{array}$ & $\begin{array}{l}\$ 0 \\
\$ 0 \\
\$ 0\end{array}$ & $\begin{array}{l}\$ 0 \\
\$ 0 \\
\$ 0\end{array}$ & $\begin{array}{r}\$ 0 \\
. \quad \$ 0 \\
\$ 0\end{array}$ & $\begin{array}{l}\$ 0 \\
\$ 0 \\
\$ 0\end{array}$ & $\begin{array}{l}\$ 63,515 \\
\$ 63,515 \\
\$ 127,030\end{array}$ \\
\hline $\begin{array}{l}\text { Unfunded Operating Costs } \\
\text { Candidate FOOT Service Development } \\
\text { Local } \\
\text { Subtotal (Unfunded Revenues) }\end{array}$ & $\begin{array}{c}\$ 185,394 \\
\$ 1,887,584 \\
\$ 2,072,977\end{array}$ & $\begin{array}{c}\$ 194,663 \\
\$ 4,143,138 \\
\$ 4,337,801\end{array}$ & $\begin{array}{c}\$ 0 \\
\$ 4,757,528 \\
\$ 4,575,528\end{array}$ & $\begin{array}{c}\$ 0 \\
\$ 4,995,405 \\
\$ 4,995,405\end{array}$ & $\begin{array}{c}\$ 0 \\
\$ 5,245,174 \\
\$ 5,245,174\end{array}$ & $\begin{array}{c}\$ 380,057 \\
\$ 21,028,829 \\
\$ 21,408,885\end{array}$ \\
\hline TOTAL & $\$ 2,200,007$ & $\$ 4,337,801$ & $\$ 4,757,528$ & $\$ 4,995,405$ & $\$ 5,245,174$ & $\$ 21, \$ 35,915$ \\
\hline
\end{tabular}

'Operating costs are inflated at 5 percent per year.

${ }^{2}$ Bus service operating costs use fully-allocated system costs and are then reduced by projected fare revenues. Actual incremental costs may be less for initial route expansion. 
Table ES-12

VOTRAN Transit Development Plan

Distribution of Estimated Capital Costs of Recommendations Among Potential Funding Sources by Fiscal Year ${ }^{1}$

\begin{tabular}{|c|c|c|c|c|c|c|}
\hline Action & FY 2003 & FY 2004 & FY 2005 & FY 2006 & Fr 2007 & TOTAL \\
\hline $\begin{array}{l}\text { B. Bus Shelters/Amenilies } \\
\text { FTA } 5307(100 \%) \\
\end{array}$ & $\$ 91,126$ & $\$ 95,683$ & $\$ 100,467$ & $\$ 105,490$ & $\$ 110,765$ & $\$ 503.531$ \\
\hline $\begin{array}{l}\text { 7. Bicycle Racks at Stops/Transfer Points } \\
\text { Unfunded Local }\langle 100 \%) \\
\end{array}$ & $\$ 1,785$ & $\$ 1,874$ & $\$ 1, \$ 52$ & $\$ 0$ & $\$ 0$ & $\$ 5,511$ \\
\hline $\begin{array}{l}\text { 9. Superstcps } \\
\text { FTA } 5307 \\
\text { Unfunded Local }\end{array}$ & $\begin{array}{c}\$ 70,356 \\
\$ 0 \\
\end{array}$ & $\begin{array}{c}\$ 36,937 \\
\$ 0\end{array}$ & $\$ 0$ & $\begin{array}{l}\text { \$o } \\
\text { \$o }\end{array}$ & $\begin{array}{c}\$ 0 \\
\$ 42,759 \\
\end{array}$ & $\begin{array}{c}\$ 107,293 \\
\$ 42,759 \\
\end{array}$ \\
\hline $\begin{array}{l}\text { 11. Bus Replacement } \\
\text { FTA } 5307 \\
\text { STP } \\
\end{array}$ & $\begin{array}{l}\$ 334,522 \\
\$ 799,950 \\
\end{array}$ & $\begin{array}{l}\$ 0 \\
\$ 0 \\
\end{array}$ & $\$ 0$ & $\begin{array}{c}\$ 1,027,377 \\
\$ 750.900 \\
\end{array}$ & $\begin{array}{l}\$ 627,610 \\
\$ 791,550 \\
\end{array}$ & $\begin{array}{l}\$ 1,989,509 \\
\$ 2,342,400 \\
\end{array}$ \\
\hline $\begin{array}{l}\text { 11. Bus Expansion } \\
\text { FTA } 5307(100 \%)\end{array}$ & $\$ 509,354$ & $\$ 948,086$ & $\$ 0$ & $\$ 0$ & $\$ 0$ & $\$ 1,457,450$ \\
\hline $\begin{array}{l}\text { 11. Paratransit Vehicle Replacement } \\
\text { FTA } 5307 \text { (100\%) }\end{array}$ & $\$ 206,839$ & $\$ 360,219$ & $\$ 378,230$ & $\$ 0$ & . $\$ 190,170$ & $\$ 0$ \\
\hline $\begin{array}{l}\text { 16. Interiocal Agreement for Commuter Rail Demo Project } \\
\text { Unfunded Local (100\%) }\end{array}$ & $\$ 2,043,333$ & $\$ 0$ & $\$ 0$ & $\$ 0$ & $\$ 0$ & $\$ 2,043,333$ \\
\hline $\begin{array}{l}\text { 19. Capitalized Maintenance } \\
\text { FTA } 5307 \\
\text { STP } \\
\end{array}$ & $\begin{array}{c}\$ 1,455,099 \\
\$ 0 \\
\end{array}$ & $\begin{array}{l}\$ 940,171 \\
\$ 622.350\end{array}$ & $\begin{array}{l}\$ 959,205 \\
\$ 899,000 \\
\end{array}$ & $\begin{array}{l}\$ 1,672,051 \\
\$ 0\end{array}$ & $\begin{array}{l}\$ 1,771,805 \\
\$ 0\end{array}$ & $\begin{array}{l}\$ 6,798,331 \\
\$ 1,321,350 \\
\end{array}$ \\
\hline $\begin{array}{l}\text { 20. Maintenance Equipmentushop Tools } \\
\text { FTA } 5307 \text { [100\%] }\end{array}$ & $\$ 12,078$ & $\$ 12,681$ & $\$ 13,315$ & $\$ 13.981$ & $\$ 54,6 B D$ & $\$ 108.735$ \\
\hline $\begin{array}{l}\text { 21. Ofrice Equipment } \\
\text { FTA } 5307(100 \%)\end{array}$ & $\$ 70,000$ & $\$ 193,812$ & $51,200,318$ & $\$ 332,720$ & $\$ 60,000$ & $\$ 1,856,850$ \\
\hline $\begin{array}{l}\text { 22. Computor Soltware } \\
\text { FTA } 5307(100 \%)\end{array}$ & $\$ 545,207$ & $\$ 267,452$ & $\$ 300,000$ & $\$ 200,000$ & $\$ 139,082$ & $\$ 1,451,741$ \\
\hline $\begin{array}{l}\text { 23. Facisity Renovation } \\
\text { FTA } 5307 \text { (100\%) }\end{array}$ & $\$ 47,600$ & $\$ 21,230$ & $\$ 22,292$ & $\$ 23,406$ & $\$ 24,576$ & $\$ \$ 139,104$ \\
\hline $\begin{array}{l}\text { 24. Service Vehicle Replscement } \\
\text { FTA } 5307(100 \%)\end{array}$ & $\$ 128,649$ & $\$ 90.054$ & $\$ 0$ & $\$ 49,642$ & $\$ 104.249$ & $\$ 372.594$ \\
\hline $\begin{array}{l}\text { 25. Vanpool Vehicle Reglacement/Expansion } \\
\text { FTA 5307 (100\%) }\end{array}$ & $\$ 151,016$ & $\$ 253.707$ & $\$ 166,495$ & $\$ 384,604$ & $\$ 293,690$ & $\$ 1,249.520$ \\
\hline $\begin{array}{l}\text { 33. Increase Frequency on Beach Troliey } \\
\text { Unfunded Local (100\%) }\end{array}$ & $\$ 264.677$ & $\$ 267,411$ & 50 & $\$ 0$ & 50 & $\$ 522,088$ \\
\hline $\begin{array}{l}\text { 37. Increase Service Frequency on Route } 60 \\
\text { Unfunded Local (100\%) }\end{array}$ & $\$ 0$ & $\$ 632,063$ & $\$ 0$ & $\$ 0$ & $\$ 0$ & $\$ 623,063$ \\
\hline $\begin{array}{l}\text { 42. Implement Commuter Rail Feeder Service } \\
\text { Unfunded Local (100\%) }\end{array}$ & $\$ 0$ & $\$ 288,175$ & $\$ 0$ & $\$ 0$ & $\$ 0$ & $\$ 288,175$ \\
\hline $\begin{array}{l}\quad \text { Funded Capital Costs } \\
\text { FTA } 5307 \\
\text { STP } \\
\text { LOCal } \\
\text { Subtotal (Funded Revenues) }\end{array}$ & $\begin{array}{c}\$ 3,620,846 \\
\$ 799,950 \\
\$ 0 \\
\$ 4,420,796\end{array}$ & $\begin{array}{c}\$ 3.220 .042 \\
\$ 622,350 \\
\$ 0 \\
\$ 3,842.392 \\
\end{array}$ & $\begin{array}{c}\$ 3,140,322 \\
\$ 699,000 \\
\$ 0 \\
\$ 3,839,322\end{array}$ & $\begin{array}{c}\$ 3,809,271 \\
\$ 750,900 \\
\$ 0 \\
\$ 4,158.185 \\
\end{array}$ & $\begin{array}{c}\$ 3,378,635 \\
\$ 791,550 \\
\$ 0 \\
\$ 4.168 .185 \\
\end{array}$ & $\begin{array}{c}\$ 17.167,116 \\
\$ 3,663,750 \\
\$ 0 \\
\$ 20.830 .856 \\
\end{array}$ \\
\hline $\begin{array}{l}\text { Unfunded Capital Costs } \\
\text { Local } \\
\text { Subtotal (Unfunded Revenues) } \\
\text { Total }\end{array}$ & 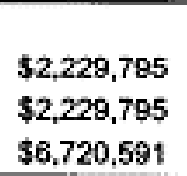 & $\begin{array}{l}\$ 1,189,523 \\
\$ 1,189,523 \\
\$ 5,031,915\end{array}$ & $\begin{array}{c}\$ 1,852 \\
\$ 1,852 \\
\$ 3,841,174 \\
\end{array}$ & $\begin{array}{c}\$ 0 \\
\$ 0 \\
\$ 4,560,171\end{array}$ & $\begin{array}{c}\$ 42,759 \\
\$ 42,759 \\
\$ 4,210,944\end{array}$ & $\begin{array}{l}\$ 3,533,929 \\
\$ 3,533,929 \\
\$ 24,364,795\end{array}$ \\
\hline
\end{tabular}

${ }^{4}$ Capital costs are inflated at 5 percent per year. 
Table ES-13

VOTRAN Transit Development Plan

Operating and Capital Budget Summary

Projected Expenses, Revenues, and Unfunded Needs

\begin{tabular}{|c|c|c|c|c|c|c|}
\hline Item & FY 2003 & FY 2004 & FY 2005 & FY 2006 & FY 2007 & TOTAL \\
\hline \multicolumn{7}{|l|}{ OPERATING } \\
\hline Original VOTRAN Operating Costs & $\$ 13,799,734$ & $\$ 14,325,923$ & $\$ 14,873,160$ & $\$ 15,442,287$ & $\$ 16,034,178$ & $\$ 74,475,282$ \\
\hline Projected Increase in ADA Service Costs & $\$ 201,376$ & $\$ 209,431$ & $\$ 217,808$ & $\$ 226,521$ & $\$ 235,581$ & $\$ 1,090,717$ \\
\hline $\begin{array}{l}\text { Cperating Costs resulting from Funded } \\
\text { Recommendations }\end{array}$ & $\$ 127,030$ & \$o & $\$ 0$ & $\$ 0$ & $\$ 0$ & $\$ 127,030$ \\
\hline $\begin{array}{l}\text { Operaling Costs resulting from Unfundod } \\
\text { Recommendations }\end{array}$ & $\$ 2,072,977$ & $\$ 4,337,801$ & $\$ 4,757,528$ & $\$ 4,995,405$ & $\$ 5.245,174$ & $\$ 21,408,885$ \\
\hline Revised Operating Costs & $\$ 16,201,117$ & $\$ 18,873,155$ & $\$ 19,848,496$ & $\$ 20,664,213$ & $\$ 21,514,933$ & $\$ 97,101,914$ \\
\hline Original VOTRAN Operating Revenue & $\$ 14,001,110$ & $\$ 14,227,362$ & $\$ 14,396,854$ & $\$ 14,617,514$ & $\$ 14,850,097$ & $\$ 72,092,937$ \\
\hline Additional Operating Funding Required & $\$ 2,200,007$ & $\$ 4,645,793$ & $\$ 5,451,642$ & $\$ 6,048,699$ & $\$ 6,664,836$ & $\$ 25,008,977$ \\
\hline \multicolumn{7}{|l|}{ CAPITAL } \\
\hline $\begin{array}{l}\text { Capitsi Costs resulting from Funded } \\
\text { Recommendations }\end{array}$ & $\$ 4,420,796$ & $\$ 3,842,392$ & $\$ 3,839,322$ & $\$ 4, \$ 60,171$ & $\$ 4,168.185$ & $\$ 20,830,866$ \\
\hline $\begin{array}{l}\text { Capital Costs resulting from Unfunded } \\
\text { Recommendations }\end{array}$ & $\$ 2,299,795$ & $\$ 1,189,523$ & $\$ 1,852$ & $\$ 0$ & $\$ 42,759$ & $\$ 3,533,929$ \\
\hline Revised Capital Costs & $\$ 6.720,691$ & $\$ 5,031,915$ & $\$ 3,841,174$ & $\$ 4,560,171$ & $\$ 4,210,944$ & $\$ 24,364,796$ \\
\hline Original VOTRAN Capital Revenue & $\$ 4,534,380$ & $\$ 3,987,897$ & $\$ 3,964,547$ & $\$ 4,849,449$ & $\$ 4,389,096$ & $\$ 21,725,359$ \\
\hline Additional Capital Funding Required & $\$ 2,186,211$ & $\$ 1,044,018$ & $(\$ 123,373)$ & $(\$ 289,278)$ & $(\$ 178,142)$ & $\$ 2,639,436$ \\
\hline TOTAL COSTS & $\$ 22,921,708$ & $\$ 23,905,070$ & $\$ 23,689,670$ & $\$ 25,244,384$ & $\$ 25,725,877$ & $\$ 121,466,709$ \\
\hline TOTAL REVENUE & $\$ 18,535,490$ & $\$ 18,215,259$ & $\$ 18,361,401$ & $\$ 19,466,963$ & $\$ 19,239,183$ & $\$ 93,818,296$ \\
\hline $\begin{array}{l}\text { TOTAL ADDITIONAL FUNDING } \\
\text { REQUIRED }\end{array}$ & $\$ 4,386,218$ & $\$ 5,689,811$ & $\$ 5,328,269$ & $\$ 5,757,421$ & $\$ 6,496,694$ & $\$ 27,648,413$ \\
\hline
\end{tabular}

'Operating and capital costs for recommendations are inflated at 5 percent per year.

2Operating costs for recommendations related to bus service improvements/modifications use fully-allocated system costs and are then reduced by projected fare revenues, therefore no changes to the "Original VOTRAN Operating Revenue" figures were necessary. 